bryg. dr hab. inż. Rafał Porowskia,c)*, mł. kpt. inż. Paweł Bańkowskib), mł. bryg. mgr inż. Wojciech Klapsac), mgr inż. Mariola Starzomskaa), mgr inż. Artur Więckowskia)

\author{
a)Wydział Inżynierii Środowiska, Geomatyki i Energetyki, Politechnika Świętokrzyska / Faculty of Environmental, Geomatic and \\ Energy Engineering, Kielce University of Technology \\ b)Wydział Inżynierii Bezpieczeństwa Pożarowego, Szkoła Główna Służby Pożarniczej / Faculty of Fire Protection Engineering, Main \\ School of Fire Service \\ c) Centrum Naukowo-Badawcze Ochrony Przeciwpożarowej - Państwowy Instytut Badawczy / Scientific and Research Centre for Fire \\ Protection - National Research Institute \\ *Autor korespondencyjny / Corresponding author: rporowski@cnbop.pl
}

\title{
Modelowanie CFD wentylacji pożarowej w tunelu drogowym
}

\author{
CFD Modelling of Fire Ventilation in Road Tunnels \\ CFD-моделирование пожарной вентиляции в автомобильном тоннеле
}

\begin{abstract}
ABSTRAKT
Cel: Celem pracy było wykonanie symulacji numerycznej rozwoju pożaru w tunelu drogowym za pomocą programu Fire Dynamics Simulator. Na tej podstawie została dokonana analiza wpływu mocy źródła pożaru na efektywność działania systemu wentylacji pożarowej. W pierwszej części artykułu przedstawiono zagadnienia związane z rozwojem pożaru. Skupiono się na aspektach teoretycznych parametrów, takich jak: rozchodzenie się dymu, rozwój pożaru, widzialność, szybkość wydzielania ciepła oraz temperatura maksymalna. Systemy wentylacji pożarowej, które są stosowane w tunelach drogowych zostały przedstawione na schematach, a także omówione zostały zasady ich działania. Kolejną część artykułu poświęcono przedstawieniu podstaw teoretycznych programu Fire Dynamics Simulator. Ostatnia część pracy zawiera opis przeprowadzonych badań oraz analizę i porównanie wyników. W części badawczej wykonano symulacje czterech scenariuszy, w zależności od mocy pożaru. Zebrane dane zostały poddane analizie. Sprawdzono, jak zachowuje się pożar w przestrzeni zamkniętej w zależności od mocy jego źródła. Dodatkowo przetestowano efektywność działania zastosowanego systemu wentylacji. Łącznie wykonano symulacje numeryczne z mocami pożaru: $202 \mathrm{MW}, 157 \mathrm{MW}, 119 \mathrm{MW}$ oraz $67 \mathrm{MW}$.

Metodologia: Artykuł został opracowany na podstawie przeglądu literatury i dostępnych w niej wyników prac naukowych dotyczących dynamiki zjawiska pożaru w tunelach drogowych, jak również badań numerycznych CFD w programie Fire Dynamics Simulator.

Wnioski: Na podstawie wykonanych badań numerycznych przybliżono zjawiska, jakie zachodzą w trakcie pożaru w tunelu drogowym. Otrzymane dane można analizować i interpretować, wyciągając przy tym wnioski, które mogą zwiększyć bezpieczeństwo w tunelach. Jednym z najważniejszych aspektów, który ma bezpośredni wpływ na bezpieczeństwo ludzi podczas pożaru jest dobór odpowiedniego systemu wentylacji. Na rynku istnieje wiele rozwiązań systemowych, posiadających zarówno wady, jak i zalety. W badanych przypadkach wykorzystano wentylację wzdłużną wraz z dwoma wentylatorami wywiewnymi. Wentylacja wzdłużna wytwarzała przepływ powietrza o prędkości $2 \mathrm{~m} / \mathrm{s}$ w całym przekroju tunelu. Na podstawie otrzymanych wyników można stwierdzić, że przepływ powietrza o prędkości $2 \mathrm{~m} / \mathrm{s}$ ogranicza rozprzestrzenianie się ciepła na wysokości 1,8 m od poziomu podłoża tunelu, niezależnie od mocy pożarów przyjętych w badaniach. Najwcześniej temperatura zaczęła wzrastać dla pożaru o mocy 119 MW, a najpóźniej dla pożaru o mocy $67 \mathrm{MW}$. W dalszych częściach tunelu temperatura zmieniała się w wąskim zakresie i nie przekroczyła $22^{\circ} \mathrm{C}$. Temperatura nad źródłem dochodziła do wartości $700^{\circ} \mathrm{C}$, natomiast za centrum pożaru maksymalna temperatura wynosiła około $1200^{\circ} \mathrm{C}$.
\end{abstract}

Słowa kluczowe: wentylacja pożarowa, pożary w tunelach drogowych, modelowanie pożarów

Typ artykułu: oryginalny artykuł naukowy

Przyjęty: 05.12.2018; Zrecenzowany: 11.12.2018; Zatwierdzony: 21.12.2018;

Identyfikatory ORCID autorów: R. Porowski - 0000-0001-7912-4222; W. Klapsa - 0000-0002-6481-587X;

Procentowy wkład merytoryczny: R. Porowski - 40\%; P. Bańkowski - 30\%; W. Klapsa - 10\%; M. Starzomska - 10\%; A. Więckowski - 10\%;

Proszę cytować: BiTP Vol. 52 Issue 4, 2018, pp. 140-166, https://dx.doi.org/10.12845/bitp.52.4.2018.9;

Artykuł udostępniany na licencji CC BY-SA 4.0 (https://creativecommons.org/licenses/by-sa/4.0/).

\section{ABSTRACT}

Aim: The purpose of this work was to perform numerical simulation of fire development in a road tunnel using the Fire Dynamics Simulator (FDS) programme. On this basis, an analysis of the impact of the fire source's power on the effectiveness of the fire ventilation system was performed. The first stage of the work presents issues related to fire development. The focus was on presenting the theoretical part of the parameters, such as smoke propagation, fire development, visibility, heat release rate and maximum temperature. The next stage of the article focuses on presenting the theoretical foundations about the Fire Dynamics Simulator program. The last stage of the work contains a description of the conducted research, as well as the 
analysis and comparison of results. In the research part, simulations of 4 scenarios were carried out, depending on the fire power. The collected data was analysed and conclusions were drawn. It was checked how a fire in a confined space behaves depending on the power of the source. In addition, the effectiveness of the ventilation system used was tested.

Introduction: Numerical simulations are used to improve fire safety in road tunnels. Numerical calculations allow to assess the suitability of the fire protection systems used. One such programme is the Fire Dynamics Simulator, which was discussed at work. In addition, theoretical issues related to fire development were presented. Issues such as maximum temperature, visibility, the process of smoke propagation and the power of fire were raised. Fire ventilation systems that are used in road tunnels are presented in the diagrams, along with the principles of their operation discussed. In total, numerical simulations with fire performance were performed: $202 \mathrm{MW}, 157 \mathrm{MW}, 119 \mathrm{MW}$ and $67 \mathrm{MW}$.

Methodology: The article was compiled on the basis of the review of literature available in the publications of the results of scientific works on the dynamics of the fire phenomenon in road tunnels, as well as numerical CFD studies in the Fire Dynamics Simulator program.

Conclusions: Based on the numerical tests carried out, the phenomena that occur during a fire in a road tunnel are approximated. The data received can be analysed and interpreted, and conclusions can be drawn to increase safety in tunnels. One of the most important aspects that has a direct impact on the safety of people during a fire is the selection of an appropriate ventilation system. There are many system solutions on the market that have both pros and cons. In the cases studied, longitudinal ventilation was used along with two exhaust fans. Longitudinal ventilation generated airflow at the velocity of $2 \mathrm{~m} / \mathrm{s}$ in the entire tunnel cross-section. Based on the obtained results, it can be concluded that the airflow rate of $2 \mathrm{~m} / \mathrm{s}$ limits the spread of heat at a height of $1.8 \mathrm{~m}$ from the ground level of the tunnel, regardless of the power of fires adopted in the tests. The earliest temperature increase occurred for a $119 \mathrm{MW}$ fire, and at the latest for a fire of $67 \mathrm{MW}$. In the further parts of the tunnel, the temperature changed in a narrow range and did not exceed $22^{\circ} \mathrm{C}$. The temperature over the source reached $700^{\circ} \mathrm{C}$, while the centre of the fire reached the maximum temperature of $1200^{\circ} \mathrm{C}$.

Keywords: fire ventilation, fires in road tunnels, fire modelling

Type of article: original scientific article

Received: 05.12.2018; Reviewed: 11.12.2018; Accepted: 21.12.2018;

Authors' ORCID IDs: R. Porowski - 0000-0001-7912-4222; W. Klapsa - 0000-0002-6481-587X;

Percentage contribution: R. Porowski - 40\%; P. Bańkowski - 30\%; W. Klapsa - 10\%; M. Starzomska - 10\%; A. Więckowski - 10\%;

Please cite as: BiTP Vol. 52 Issue 4, 2018, pp. 140-166, https://dx.doi.org/10.12845/bitp.52.4.2018.9;

This is an open access article under the CC BY-SA 4.0 license (https://creativecommons.org/licenses/by-sa/4.0/).

\section{АННОТАЦИЯ}

Цель: Целью работы было выполнение численного моделирования развития пожара в автомобильном тоннеле с использованием программы Fire Dynamics Simulator. На этой основе был проведен анализ влияния силы источника пожара на эффективность системы пожарной вентиляции. В первой части работы представлены вопросы, связанные с развитием пожара. Основное внимание было уделено аспектам теоретических параметров, таких как: распространение дыма, развитие огня, видимость, скорость тепловыделения и максимальная температура. Системы пожарной вентиляции, которые используются в автодорожных туннелях, представлены на схемах, а также оговорены принципы их работы. Следующая часть статьи посвящена изложению теоретических основ программы Fire Dynamics Simulator. Последняя часть работы содержит описание проведенного исследования, а также анализ и сравнение результатов. В исследовательской части были смоделированы четыре сценария, в зависимости от силы пожара. Были проанализированы собранные данные. Пожар в замкнутом пространстве проверялся в зависимости от мощности его источника, кроме того, проверялась эффективность системы вентиляции. Всего было проведено численное моделирование со следующими характеристиками пожара: 202 МВт, 157 MBT, 119 МBт и 67 МВт.

Методология: Статья разработана на основе литературного обзора имеющихся результатов научных исследований динамики пожаров в автодорожных туннелях, а также численных исследований CFD в программе Fire Dynamics Simulator.

Выводы: На основании проведенных численных испытаний были симулированы похожие явления, возникающие при пожаре в автодорожном туннеле. Полученные данные можно анализировать и интерпретировать, делая выводы, которые могут повысить безопасность в туннелях. Одним из наиболее важных аспектов, который напрямую влияет на безопасность людей во время пожара, является выбор подходящей системы вентиляции. На рынке существует множество системных решений, которые имеют как преимущества, так и недостатки. В изученных случаях использовалась продольная вентиляция вместе с двумя вытяжными вентиляторами. При продольной вентиляции создавался поток воздуха со скоростью 2 м/сек по всему поперечному сечению туннеля. На основании полученных результатов можно сделать вывод, что скорость воздушного потока 2 м/сек ограничивает распространение тепла на высоте 1,8 м от уровня земли в туннеле независимо от силы пожара, принятой в ходе испытаний. Быстрее всего началось повышение температуры при пожаре 119 МВт, а самое позднее повышение температуры произошло при пожаре 67 МВт. В дальних частях туннеля температура изменялась в узком диапазоне и не превышала $22^{\circ} \mathrm{C}$. Температура над источником достигала $700^{\circ} \mathrm{C}$, а очаг пожара достигал максимальной температуры $1200^{\circ} \mathrm{C}$.

Ключевые слова: пожарная вентиляция, пожары в автодорожных туннелях, моделирование пожаров

Вид статьи: оригинальная научная статья

Принята: 05.12.2018; Рецензирована: 11.12.2018; Одобрена: 21.12.2018;

Идентификаторы ORCID авторов: R. Porowski - 0000-0001-7912-4222; W. Klapsa - 0000-0002-6481-587X;

Процентное участие в подготовке статьи: R. Porowski - 40\%; P. Bańkowski - 30\%; W. Klapsa - 10\%; M. Starzomska - 10\%; A. Więckowski - 10\%;

Просим ссылаться на статью следующим образом: BiTP Vol. 52 Issue 4, 2018, pp. 140-166, https://dx.doi.org/10.12845/bitp.52.4.2018.9;

Настоящая статья находится в открытом доступе и распространяется в соответствии с лицензией CC BY-SA 4.0 (https://creativecommons.org/ licenses/by-sa/4.0/). 


\section{Wprowadzenie}

Pożar w tunelu drogowym to bardzo niebezpieczne zjawisko. Nagromadzenie na małej przestrzeni potencjalnych materiałów palnych, ograniczone możliwości usuwania dymu i gorących gazów pożarowych, utrudnione dotarcie do dróg ucieczki, a także źle dobrane systemy wentylacji to tylko nieliczne czynniki zagrażające bezpieczeństwu użytkowników tuneli drogowych. Dynamika rozwoju pożaru w tunelu znacznie różni się od tej na przestrzeni otwartej. Ograniczona przestrzeń sprzyja szybkiemu gromadzeniu się dymu, co skutkuje zmniejszeniem widoczności. W takich warunkach użytkownicy obiektu mogą nie odnaleźć drogi ewakuacyjnej lub drogi ucieczki. Dodatkowo wysoka temperatura powoduje szybkie rozprzestrzenianie się ognia na kolejne materiały palne znajdujące się w pobliżu źródła pożaru. Źle dobrana wentylacja może nasilać to zjawisko, a także wywoływać efekt mieszania się warstw dymu. Skutkiem mieszania się warstw dymu ze świeżym powietrzem będzie ograniczenie widoczności. W celu poznania, w jaki sposób pożar rozwija się w tunelach drogowych, wykonuje się badania. Eksperymenty mogą przybrać różne formy. Najwięcej danych można uzyskać za pomocą testów przeprowadzanych w skali 1:1. Wykonywane są także badania w mniejszych skalach. Aby oszacować konkretny parametr, można posłużyć się specjalnie opracowanymi wzorami. Obliczenia bazują na podstawowych parametrach pożaru. Należą do nich między innymi moc pożaru, powierzchnia palącego się materiału oraz ciepło spalania.

\section{Rozwój pożaru w tunelu drogowym}

Pożary w tunelach drogowych znacznie różnią się od pożarów w typowych budynkach, np. mieszkaniowych lub użyteczności publicznej. Ograniczony dostęp świeżego powietrza, jak również niewielka kubatura, w której przebiega proces spalania wybranych materiałów oraz wyrobów budowlanych, może powodować generację ciepła oraz toksycznych produktów spalania. Dodatkowo na niewielkiej powierzchni zgromadzone są materiały palne, na które pożar może się z łatwością rozprzestrzeniać. Wykorzystane systemy wentylacji pożarowej mają więc znaczący wpływ na rozwój dynamiki tego zjawiska. Sprawne usuwanie dymu oraz gorących gazów pożarowych ma kluczowe znaczenie w ograniczeniu rozprzestrzeniania się pożaru i w przeprowadzeniu efektywnych działań ratowniczo-gaśniczych. Do prawidłowej oceny dynamiki rozwoju pożaru w tunelu wykorzystuje się parametry opisujące to zjawisko. Jednym z nich jest tworzenie się i zaleganie $w$ tunelu warstw dymu. Tworzenie się warstwy dymu zależy między innymi od prędkości przepływu powietrza, a także od siły wyporu, która powstaje w wyniku procesu spalania materiałów palnych [1]. Dym składa się w ogólnym podejściu z toksycznych produktów spalania oraz świeżego powietrza. W procesie spalania następuje ogrzewanie dymu. Dzięki siłom wyporu gorący dym zostaje przetransportowany w górne strefy tunelu. W pierwszych etapach rozwoju pożaru odnotowuje się duże stężenie gazowych produktów spalania w strefie podsufitowej. Najczęściej występującymi gazami w atmosferze

\section{Introduction}

Fires in road tunnels are extremely dangerous event. The accumulation of potentially combustible materials in a small space, limited possibilities of removing smoke and hot fire gases, inhibited access to escape routes, and poorly selected ventilation systems are among the factors which threaten the safety of road tunnel users. The fire development dynamics in a tunnel differs significantly from the one in open spaces. A confined space results in the quick accumulation of smoke which reduces visibility. Under such conditions, the facility users may not find the evacuation or escape route. In addition, high temperature results in the rapid spread of fire to other combustible materials near the fire source. An ill-matched ventilation system can intensify this phenomenon and cause smoke layers to mix up. The mixing of smoke layers with fresh air result in limited visibility. Tests are conducted to identify how fires can spread in road tunnels. These experiments can take various forms. Most data can be obtained from 1:1 tests. Smaller-scale tests are also carried out. In order to estimate a given parameter, one can use specially developed formulas. Such calculations are based on the underlying parameters of a fire which include the heat release rate, the area of material on fire, and the heat of combustion.

\section{Fire development in a road tunnel}

Fires in road tunnels differ significantly from those in regular buildings, such as residential or public buildings. The limited amount of fresh air, as well as small cubage in which the combustion of selected materials and building materials takes place, may result in the generation of heat and toxic combustion products. In addition, in the case of tunnels, flammable materials are located within a small area and the fire can easily spread onto them. Therefore, the fire ventilation systems used significantly influence the dynamics of this phenomenon. Effective removal of smoke and hot fire gases is of key significance in limiting the spread of the fire, and in the performance of effective rescue and firefighting operations. In order to accurately evaluate the dynamics of the fire spread inside a tunnel, one can use certain parameters which describe this phenomenon. One of these is the emergence and lingering of smoke layers inside the tunnel. The creation of the layer of smoke depends on air movement velocity and on the buoyant force resulting from the combustion of flammable materials [1]. Smoke is generally composed of toxic products of combustion and fresh air. During the combustion process, smoke is heated up. Through the buoyant force, hot smoke is transported to the upper segments of the tunnel. In the first stages of fire development, a high concentration of gaseous combustion products can be recorded in the ceiling zone. The most common gases in a fire atmosphere, which pose a threat 
pożarowej, które stwarzają zagrożenie dla człowieka są: tlenek węgla, cyjanowodór, chlorowodór, tlenki siarki, tlenki azotu oraz bromowodór [2-3]. Na rycinie 1 pokazano sposób rozchodzenia się dymu przy prędkościach przepływu powietrza od 0 do $1 \mathrm{~m} / \mathrm{s}$. Przepływ lotnej fazy gazowej, powstałej w wyniku spalania, nie jest niczym wymuszony. Działają na ten przepływ tylko i wyłącznie siły wyporu powietrza z kolumny konwekcyjnej pożaru. Skutkuje to przemieszczaniem się dymu w obu kierunkach. Nad źródłem pożaru występuje bardzo wyraźne oddzielenie pomiędzy warstwami dymu. to human life, are carbon monoxide, hydrogen cyanide, hydrogen chloride, sulphur oxides, nitrogen oxides and hydrogen bromide [2-3]. Figure 1 presents the manner of smoke propagation with air velocity between $0-1 \mathrm{~m} / \mathrm{s}$. The flow of the volatile gas phase resulting from combustion is not forced in any way. This flow is influenced solely by the buoyant force of the air from the fire convection column. This results in smoke movement in both directions. Above the fire source, there is a clear division between the layers of smoke.

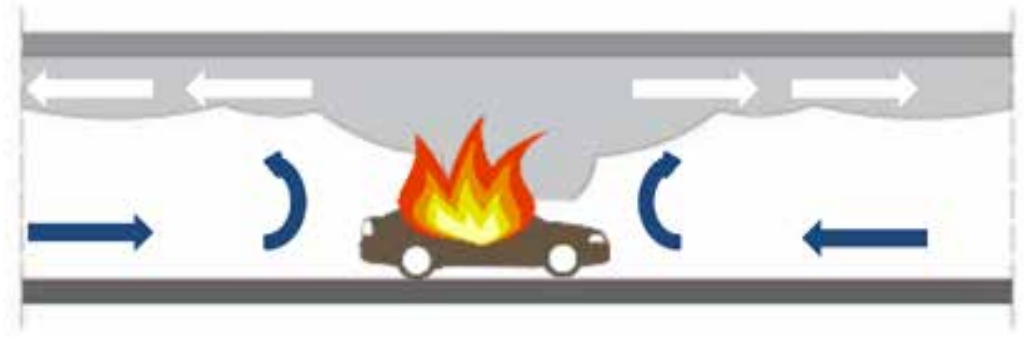

Rycina 1. Przemieszczanie się warstwy dymu przy prędkościach 0-1 m/s [1]

Figure 1. Smoke layer movement with a velocity between $0-1 \mathrm{~m} / \mathrm{s}$ [1]

Wymuszenie kierunku przepływu dymu nastąpi wówczas, gdy prędkość przepływu powietrza znajdować się będzie w przedziale 1-3 m/s. Nienaturalny napływ mas świeżego powietrza będzie powodował zatem ruch dymu $w$ kierunku zgodnym $z$ kierunkiem przepływu powietrza. Pozostała część poruszać się będzie w przeciwległą stronę. Zjawisko to nazywa się backlayering [3] i zostało zilustrowane na rycinie 2. Jest ono szczególnie niebezpieczne $z$ uwagi na ograniczanie widzialności. Przy niewielkim zakresie widzenia ludzie mogą nie odnaleźć drogi ewakuacyjnej. Dodatkowo wraz z dymem rozprzestrzeniają się toksyczne gazy, będące główną przyczyną śmierci osób przebywających $w$ tunelu podczas pożaru. Szacuje się, że dla prędkości przepływu powietrza od 1 do $3 \mathrm{~m} / \mathrm{s}$ rozpiętość cofającego się dymu może być do 25 razy większa niż wysokość tunelu. W wyniku oddziaływania napływającego powietrza następuje mieszanie się warstw dymu [1].
The smoke flow direction can be forced when the airflow velocity is within the range of 1-3 m/s. An unnatural inflow of fresh air will, therefore, result in the movement of smoke in the direction of fresh airflow while the remaining part will move in the opposite direction. This phenomenon is referred to as backlayering [3]. It is presented in Figure 2 and is especially dangerous due to limited visibility. With limited visibility, people may not find the evacuation route. In addition, the smoke carriers toxic gases which constitute the main cause of death of individuals who are inside the tunnel during the fire. It is estimated that, for airflows with a velocity of $1-3 \mathrm{~m} / \mathrm{s}$, the span of backlayering can be up to 25 times greater than the height of the tunnel. As a result of the inflowing air, the layers of smoke mix up [1].

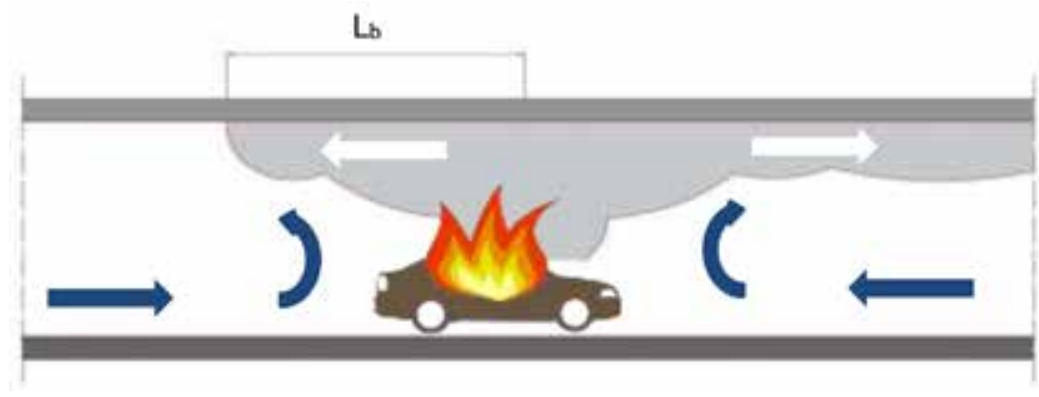

Rycina 2. Przemieszczanie się warstwy dymu przy prędkościach 1-3 m/s [1]

Figure 2. Smoke layer movement with a velocity between $1-3 \mathrm{~m} / \mathrm{s}$ [1]

Przedstawiony na rycinie 2 parametr $L_{b}$ jest to odcinek dymu, który porusza się w kierunku przeciwnym, pomimo wymuszonego ruchu świeżego powietrza. Długość tego odcinka oblicza się na podstawie równania (1) [3]:
Parameter $L_{b}$ presented in Figure 2 is a section of smoke moving in the opposite direction despite the forced movement of fresh air. The length of this section is calculated using formula (1) [3]: 


$$
L_{b}^{*}=\frac{L_{b}}{H}=0,6\left(\frac{2 g H Q}{\rho_{0} T_{0} c_{p} u_{0}^{3} A}-5\right)
$$

gdzie:

$L_{b}^{*}$ - bezwymiarowa długość odcinka cofającego się dymu;

$L_{b}$ - długość odcinka cofającego się dymu, [m];

$H$ - wysokość tunelu, [m];

$Q$ - moc pożaru, [kW];

$\rho_{0}$ - gęstość ośrodka, [kg/m³];

$T_{0}$ - temperatura powietrza, [K];

$u_{0}$-lokalne przyspieszenie przepływu powietrza, $\left[\mathrm{m} / \mathrm{s}^{2}\right]$;

$c_{p}$ - ciepło właściwe powietrza, $[\mathrm{kJ} /(\mathrm{kg} \cdot \mathrm{K})]$;

$g$ - przyśpieszenie ziemskie, $\left[\mathrm{m} / \mathrm{s}^{2}\right]$;

$A$ - powierzchnia przekroju, $\left[\mathrm{m}^{2}\right]$

Równanie opisujące bezwymiarową długość odcinka cofającego się dymu można również zapisać w zależności od bezwymiarowej szybkości wydzielania ciepła w następującej postaci algebraicznej [4]:

$$
L_{b}^{*}= \begin{cases}18,5 \ln \frac{0,81 Q^{* 1 / 3}}{u^{*}}, & Q^{*} \leq 0,15 \\ 18,5 \ln \frac{0,43}{u^{*}}, & Q^{*}>0,15\end{cases}
$$

gdzie:

$L_{b}^{*}$ - bezwymiarowa długość odcinka cofającego się dymu;

$Q^{*}$ - bezwymiarowa moc pożaru;

$u^{*}$ - prędkość wzdłużnego przepływu powietrza, [m/s].

Biorąc pod uwagę bezpieczną ewakuację osób, jak również sprawne oraz efektywne dotarcie ekip ratowniczych do miejsca pożaru, należy wyznaczyć taką prędkość przepływu powietrza, przy której ruch dymu w kierunku przeciwnym do kierunku przepływu powietrza jest niemożliwy. Prędkość ta zwana jest prędkością krytyczną. Oblicza się ją podstawie równań [4]:

$$
\begin{gathered}
u_{c}^{*}=\frac{u_{c}}{\sqrt{g H}} \\
u_{c}^{*}= \begin{cases}0,81 Q^{* 1 / 3}, & Q^{*} \leq 0,15 \\
0,43, & Q^{*}>0,15\end{cases} \\
Q_{c}^{*}=\frac{Q}{\rho_{0} c_{p} T_{0} g^{1 / 2} H^{5 / 2}}
\end{gathered}
$$

gdzie:

$u_{c}^{*}$ - bezwymiarowa prędkość krytyczna;

$u_{c}$ - prędkość krytyczna, [m/s];

$H$ - wysokość tunelu, [m];

$Q^{*}$ - bezwymiarowa moc pożaru;

$Q$ - całkowita moc pożaru, [kW];

$\rho_{0}$ - gęstość otoczenia, $\left[\mathrm{kg} / \mathrm{m}^{3}\right]$;

$T_{0}$ - temperatura powietrza, [K];

$c_{p}$ - ciepło właściwe powietrza, $[\mathrm{kJ} /(\mathrm{kg} \cdot \mathrm{K})]$;

$g$ - przyśpieszenie ziemskie, [m/s²].

Dzięki osiągnięciu prędkości krytycznej przepływu powietrza w tunelu dochodzi do obniżenia temperatury panującej w strefie podsufitowej. Dodatkowo redukcji ulegają również stężenia toksycznych produktów spalania oraz dym, co ułatwia

$$
L_{b}^{*}=\frac{L_{b}}{H}=0.6\left(\frac{2 g H Q}{\rho_{0} T_{0} c_{p} u_{0}^{3} A}-5\right)
$$

where:

$L_{b}^{*}$ - dimensionless length of the section of backlayering smoke;

$L_{b}$ - length of the section of backlayering smoke, [m];

$H$ - tunnel height, [m];

$Q$ - heat release rate, $[\mathrm{kW}]$;

$\rho_{0}$ - medium density, $\left[\mathrm{kg} / \mathrm{m}^{3}\right]$;

$T_{0}$ - air temperature, [K];

$u_{0}$ - local airflow acceleration, $\left[\mathrm{m} / \mathrm{s}^{2}\right]$;

$c_{p}$ - specific heat of air, $[\mathrm{kJ} /(\mathrm{kg} \cdot \mathrm{K})]$;

$\mathrm{g}$ - gravitational acceleration, $\left[\mathrm{m} / \mathrm{s}^{2}\right]$;

$A$ - cross-section area, $\left[\mathrm{m}^{2}\right]$

A formula describing the dimensionless length of the section of backlayering smoke can be also formulated based on the dimensionless heat release rate as follows [4]:

$$
L_{b}^{*}= \begin{cases}18.5 \ln \frac{0.81 Q^{* 1 / 3}}{u^{\star}}, & Q^{*} \leq 0.15 \\ 18.5 \ln \frac{0.43}{u^{\star}}, & Q^{*}>0.15\end{cases}
$$

where:

$L_{b}^{*}$ - dimensionless length of the section of backlayering smoke;

$Q^{*}$ - dimensionless heat release rate;

$u^{*}-$ longitudinal airflow velocity, [m/s].

Taking into account the safe evacuation of people, as well as the prompt and effective arrival of the rescue brigades on site, it is necessary to determine the air velocity at which backlayering is impossible. This is referred to as critical velocity. It is calculated using the following formulas [4]:

$$
\begin{gathered}
u_{c}^{*}=\frac{u_{c}}{\sqrt{g H}} \\
u_{c}^{*}= \begin{cases}0.81 Q^{* 1 / 3}, & Q^{*} \leq 0.15 \\
0.43, & Q^{*}>0.15\end{cases} \\
Q_{c}^{*}=\frac{Q}{\rho_{0} c_{p} T_{0} g^{1 / 2} H^{5 / 2}}
\end{gathered}
$$

where:

$u_{c}^{*}-$ dimensionless critical velocity;

$u_{c}$ - critical velocity, $[\mathrm{m} / \mathrm{s}]$;

$H$ - tunnel height, [m];

$Q^{*}$ - dimensionless heat release rate;

$\mathrm{Q}$ - total heat release rate, [kW];

$\rho_{0}-$ ambient density, $\left[\mathrm{kg} / \mathrm{m}^{3}\right]$;

$T_{0}$ - air temperature, [K];

$c_{p}$ - specific heat of air, [kJ/(kg.K)];

$g$ - gravitational acceleration, $\left[\mathrm{m} / \mathrm{s}^{2}\right]$.

When the critical velocity of airflow is reached in the tunnel, the temperature in the ceiling zone drops. In addition, the concentrations of toxic combustion products and smoke are also reduced, making it easier for victims to find an escape route. 
odnalezienie drogi ucieczki przez poszkodowanych. Niemniej jednak zbyt duży wzrost tej prędkości może spowodować mieszanie się gazów powstałych w wyniku spalania ze świeżym powietrzem, czyli rozwarstwianie się dymu. W wyniku tego może nastąpić dopływ tlenu do źródła pożaru oraz wzrost intensywności spalania. Duża prędkość przepływu powietrza skutkować może również przenoszeniem się pożaru na inne pojazdy znajdujące się w bezpośredniej bliskości od źródła ognia. W systemie wentylacji wzdłużnej duża prędkość powietrza utrudniać może dotarcie do dróg ewakuacyjnych lub stref bezpiecznych [1]. Podczas pożarów o dużej mocy w tunelach, prędkość równa $3 \mathrm{~m} / \mathrm{s}$ może nie zapobiegać powstawaniu zjawiska backlayering. Konieczne jest wtedy zwiększenie prędkości krytycznej.
However, an excessive increase in this velocity may result in the mixing of combustion gases with fresh air, i.e., the stratification of smoke. This can result in an inflow of oxygen to the source of fire, coupled with an increased combustion intensity. A high airflow velocity can also cause fire to spread to other vehicles in the immediate vicinity of the fire source. In a longitudinal ventilation system, high air velocities can make it difficult to get to escape routes or safe zones [1]. During fires with a high heat release rate, a velocity of $3 \mathrm{~m} / \mathrm{s}$ may not prevent backlayering. In such cases, it is necessary to increase the critical velocity.

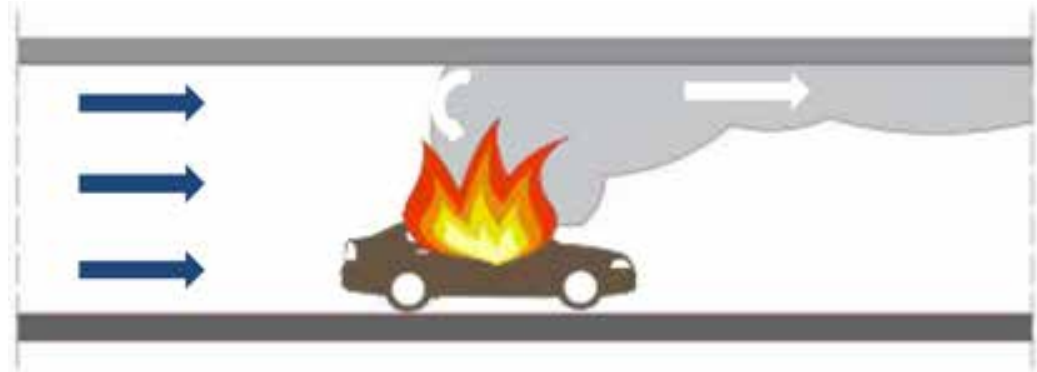

Rycina 3. Przemieszczanie się warstwy dymu przy prędkościach powyżej $3 \mathrm{~m} / \mathrm{s}$ [1]

Figure 3. Smoke layer movement with a velocity greater than $3 \mathrm{~m} / \mathrm{s}$ [1]

Wraz ze zwiększeniem się odległości od źródła pożaru można zaobserwować powstawanie jednorodnej warstwy dymu. Zacieranie się granic pomiędzy warstwami dymu związane jest z oddziaływaniem mas zimnego powietrza na płomienie. Intensyfikacja mieszania się warstw występuje natomiast przy dużych wartościach prędkości przepływu powietrza.
As the distance to the fire source grows, one can observe the emergence of a uniform layer of smoke. The blurring of boundaries between smoke layers is due to the impact of cold air masses on flames. The intensification of layer mixing takes place at high airflow velocities.

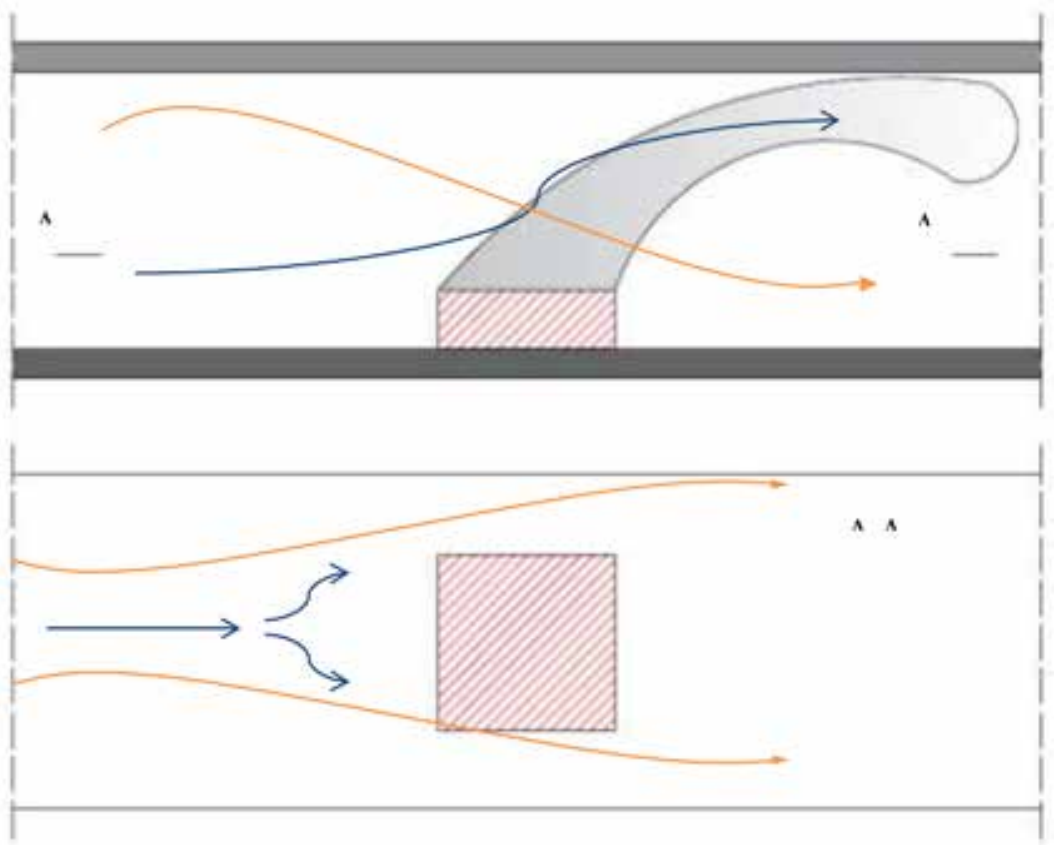

Rycina 4. Przepływ strumieni powietrza przez źródło pożaru [3]

Figure 4. Air jets flow through the fire source [3] 
Na rycinie 4 przedstawiono schemat przepływu strumieni powietrza nad źródłem pożaru. Strumienie zaznaczone kolorem pomarańczowym przepływają obok pożaru, nie powodując mieszania się warstw. Jest to wynikiem różnicy ciśnień występującej między gorącym dymem a zimnym strumieniem powietrza. Dym jest podgrzewany wówczas nad źródłem pożaru i w wyniku działania sił wyporu unosi się do góry. Kumulacja dymu pod sufitem sprawia, że zaczyna on rozchodzić się wzdłuż tunelu. Temperatura dymu maleje wraz ze zwiększaniem się odległości od źródła pożaru. Z kolei wraz ze spadkiem temperatury dymu maleje jego ciśnienie. Spadek ciśnienia ułatwia mieszanie się dymu z otaczającym go powietrzem. Kolejnym czynnikiem naruszającym mocne uwarstwienie dymu są siły bezwładności. Działanie siły bezwładności polega na mieszaniu się strumieni gazów o różnej temperaturze, bez wymiany ciepła. Liczba Richardsona ( $R i$ ) opisuje zależność pomiędzy konwekcją naturalną, a konwekcją wymuszoną gazów [3]:

$$
R_{i}=\frac{\Delta \rho g h}{\rho \Delta u^{2}}
$$

gdzie:

$\rho$ - gęstość gorącego gazu, $\left[\mathrm{kg} / \mathrm{m}^{3}\right]$;

$\Delta \rho$ - różnica gęstości, [ $\left.\mathrm{kg} / \mathrm{m}^{3}\right]$;

$g$ - przyśpieszenie ziemskie, $\left[\mathrm{m} / \mathrm{s}^{2}\right]$;

$h$ - grubość warstwy, [m];

$\Delta u$ - różnica prędkości gazu pomiędzy warstwami, [m/s].

O stabilności warstw dymu w tunelu będzie zatem świadczyła liczba Richardsona. Im wartość tej liczby będzie większa, tym wyraźniej będą oddzielone warstwy. Wraz ze zwiększaniem odległości od źródła pożaru, dym będzie opadał ku dołowi. Efekt ten wynika z utraty pędu oraz intensywnej wymiany ciepła. Istnieją specjalnie opracowane równania zachowania masy, pędu oraz energii, które opisują przepływ dymu w tunelach, przy uwzględnieniu wentylacji naturalnej. Za pomocą równania (7) oblicza się masowe natężenie przepływu dla dymu w stanie ustalonym [4]:

$$
\dot{m}(x)=\dot{m}_{0}+\beta W \int\left|u-u_{0}\right| d x
$$

gdzie:

$u_{0}$ - prędkość przepływu powietrza w dolnej warstwie, [m/s];

$\dot{m}_{0}$ - masowe natężenie przepływu powietrza, [kg/s];

$\rho$ - współczynnik porywania między warstwami;

$W$ - szerokość tunelu, [m].

Mając do dyspozycji masowe natężenie przepływu, można oszacować głębokość warstwy dymu w konkretnej odległości (x). W tym celu należy użyć następującego równania [3]:

$$
h(x)=\frac{\dot{m}(x)\left(T_{0}+\Delta T(x)\right)}{\rho_{0} T_{0} u(x) W}
$$

gdzie:

$\Delta T$ - nadmiar temperatury dymu, [K];

$\rho_{0}$ - gęstość otoczenia, $\left[\mathrm{kg} / \mathrm{m}^{3}\right]$;

$T_{0}$ - temperatura powietrza, [K];

$u(x)$ - prędkość przepływu powietrza, $[\mathrm{m} / \mathrm{s}]$;

$W$ - szerokość tunelu, [m].
Figure 4 presents the air jets flow above the fire source. The jets marked with orange flow next to the fire, not resulting in the mixing of layers. This stems from the pressure difference between the hot smoke and the cold air jet. Smoke is then heated up above the source of the fire and raised by the buoyant force. The accumulation of smoke under the ceiling causes it to spread along the tunnel. As the distance to the fire source grows, the temperature of smoke decreases. In turn, as the smoke temperature decreases, its pressure drops. The drop in pressure makes it easier for the smoke to mix up with the surrounding air. Inertia forces constitute another factor which distorts the strong stratification of smoke. The effects if inertia result in the mixing of gas streams of various temperature with no heat transfer. The Richardson number $(R i)$ describes the correlation between the natural convection and the forced convection of gasses [3]:

$$
R_{i}=\frac{\Delta \rho g h}{\rho \Delta u^{2}}
$$

where:

$\rho$ - density of hot gas, $\left[\mathrm{kg} / \mathrm{m}^{3}\right]$;

$\Delta \rho$ - difference in density, $\left[\mathrm{kg} / \mathrm{m}^{3}\right]$;

$g-$ gravitational acceleration, $\left[\mathrm{m} / \mathrm{s}^{2}\right]$

$h$ - layer thickness, [m];

$\Delta u$ - difference in gas velocity between layers, $[\mathrm{m} / \mathrm{s}]$.

Thus, the Richardson number determines the stability of smoke layers inside the tunnel. The higher its value, the more clearly the layers will be separated. As the distance to the fire source grows, smoke will descend. This effect is due to the loss of momentum and intensive heat exchange. There are special formulas for mass, momentum and energy which describe the smoke flow in tunnels, taking into account natural ventilation. Using formula (7), it is possible to calculate the mass flow rate for smoke in a steady state [4]:

$$
\dot{m}(x)=\dot{m}_{0}+\beta W \int\left|u-u_{0}\right| d x
$$

where:

$u_{0}-$ airflow velocity in the lower layer, $[\mathrm{m} / \mathrm{s}]$

$\dot{m}_{0}$ - mass flow rate of air, [kg/s];

$\rho$ - entrainment rate between the layers;

$W$ - tunnel width, [m].

With the mass flow rate known, it is possible to estimate the depth of the smoke layer at a specific distance $(x)$. To do so, one can use the following formula [3]:

$$
h(x)=\frac{\dot{m}(x)\left(T_{0}+\Delta T(x)\right)}{\rho_{0} T_{0} u(x) W}
$$

where:

$\Delta T$ - excess temperature of smoke, [K];

$\rho_{0}$ - ambient density, $\left[\mathrm{kg} / \mathrm{m}^{3}\right]$;

$T_{0}$ - air temperature, [K];

$u(x)$ - airflow velocity, $[\mathrm{m} / \mathrm{s}]$;

$W$ - tunnel width, [m]. 
Równanie (8) można jednak zastosować tylko wówczas, gdy dym nie osiągnie poziomu podłogi. Do określenia wysokości warstwy dymu należy się posłużyć następującym wzorem [3]:

$$
H_{\text {smoke }}(x)=H-h(x) \cdot[x]
$$

W równaniu (7) został wykorzystany współczynnik porywania $\beta$. Zjawisko porywania polega na przemieszczaniu się mas powietrza do górnych warstw w wyniku turbulentnego mieszania. Duże wiry wytworzone przez turbulencje przenoszą powietrze. Za pomocą następującego równania można wyróżnić trzy odrębne strefy różniące się pod względem stratyfikacji dymu [4]:

$$
F r=\frac{u_{\text {avg }}^{2}}{\sqrt{g H \Delta T_{c f} / T_{a f g}}}
$$

gdzie:

$H$ - wysokość tunelu, [m];

$T_{\text {avg }}$ - średnia temperatura gazu na całym przekroju w danej pozycji, [K];

$\Delta T_{c f}=T_{c}-T_{f}$ - różnica temperatury gazu pomiędzy sufitem

a podłogą, [K];

$g$ - przyśpieszenie ziemskie, $\left[\mathrm{m} / \mathrm{s}^{2}\right]$;

$u_{\text {avg }}=u T_{\text {avg }} / T_{a}$.

Liczne badania wykazały, że w drugiej strefie do obliczenia różnicy temperatur potrzebne jest dodatkowe równanie, które wygląda w sposób następujący [3]:

$$
\Delta T_{c f}=0,225 \frac{g H \Delta T_{\text {avg }}^{2}}{T_{\text {avg }} u_{\text {avg }}^{2}}
$$

gdzie:

$H$ - wysokość tunelu, [m];

$T_{\text {avg }}$ - średnia temperatura gazu na całym przekroju w danej pozycji, [K];

$g$ - przyśpieszenie ziemskie, $\left[\mathrm{m} / \mathrm{s}^{2}\right]$;

$u_{\text {avg }}=u T_{\text {avg }} / T_{a}$.

Średnią prędkość $\left(u_{\text {avg }}\right)$ oraz średnią temperaturę $\left(T_{\text {avg }}\right)$ konieczne do zastosowania w równaniu (11) można obliczyć na podstawie specjalnie przygotowanych do tego celu modeli. Otrzymane wartości wykorzystywane są do obliczenia liczby Froude'a. Mogą one odbiegać od rzeczywistych temperatur panujących w tunelu. Poszczególne wartości liczby Froude'a odpowiadają określonym strefom. Podziału stref dokonano na podstawie gradientu temperatur oraz jakości rozwarstwienia dymu (zob. ryc. 5). Strefa I charakteryzuje się silnym rozwarstwieniem warstw dymu oraz wartością $F r \leq 0,9$. W strefie II wartość $F r$ mieści się w granicach od 0,9 do 3,2. W tej strefie na dym działa siła wyporu oraz siła napływającego powietrza. W strefie III wartość $F r>3,2$ oraz następuje zatarcie się granic stref. Dodatkowo w każdej ze stref występują różnice temperatur pomiędzy sufitem a podłogą. W strefie I obserwuje się największą różnicę temperatur. Wynika to $z$ faktu, że gorące gazy pożarowe przemieszczają się pod sufitem, natomiast przy podłodze panuje temperatura otoczenia. W strefie III występują niewielkie różnice temperatur. Dzieje się tak, ponieważ dym wymieszał się już z powietrzem. Strefa Il to strefa przejściowa. Występują w niej różnice temperatur.
However, formula (8) can only be used if the smoke layer has not reached the floor level. In order to determine the height of the smoke layer, the following formula can be used [3]:

$$
H_{\text {smoke }}(x)=H-h(x) \cdot[x]
$$

The entrainment rate $\beta$ is used in formula (7). Entrainment consists in the air masses moving to the upper layers as a result of turbulent mixing. Large vortexes generated by turbulence move the air. Using the following formula, it is possible to differentiate between three separate zones which differ in terms of smoke stratification [4]:

$$
F r=\frac{u_{\text {avg }}^{2}}{\sqrt{g H \Delta T_{c f} / T_{a f g}}}
$$

where:

$H$ - tunnel height, [m];

$T_{\text {avg }}$ - average gas temperature throughout the entire section of a given position, [K];

$\Delta T_{c f}=T_{c}-T_{f}-$ gas temperature difference between the ceiling and the floor, [K];

$g$ - gravitational acceleration, $\left[\mathrm{m} / \mathrm{s}^{2}\right]$;

$u_{\text {avg }}=u T_{\text {avg }} / T_{a}$.

Numerous studies have demonstrated that an additional formula is needed in the second zone to calculate the temperature difference. This formula is presented below [3]:

$$
\Delta T_{c f}=0.225 \frac{g H \Delta T_{\text {avg }}^{2}}{T_{\text {avg }} u_{\text {avg }}^{2}}
$$

where:

$H$ - tunnel height, [m];

$T_{\text {avg }}$ - average gas temperature throughout the entire section of a given position, [K];

$g-$ gravitational acceleration, $\left[\mathrm{m} / \mathrm{s}^{2}\right]$;

$u_{\text {avg }}=u T_{\text {avg }} / T_{a}$.

Average velocity $\left(u_{\text {avg }}\right)$ and average temperature $\left(T_{\text {avg }}\right)$ which must be used in formula (11) can be calculated based on specially designed models. The obtained values are used to calculate the Froude number, and can differ from the actual temperatures in the tunnel. The individual values of the Froude number correspond to individual zones. The zone division was based on the temperature gradient and the quality of smoke stratification (see Fig. 5). Zone I is characterised by a strong stratification of the smoke layers and $F r \leq 0.9$. In Zone II, $F r$ is within the range of 0.9 to 3.2. In this zone, the smoke is affected by the buoyant force and the force of the incoming air. In Zone III, Fr $>3.2$ and the zone borders become blurred. In addition, in each zone there are temperature differences between the ceiling and the floor. The greatest difference in temperatures is observed in Zone I. This is due to the fact that the hot fire glasses move under the ceiling, while ambient temperature is retained near the floor. In Zone III, small temperature differences are recorded. This is because the smoke has already mixed up with air. Zone II is a transition zone where temperature differences are present. 


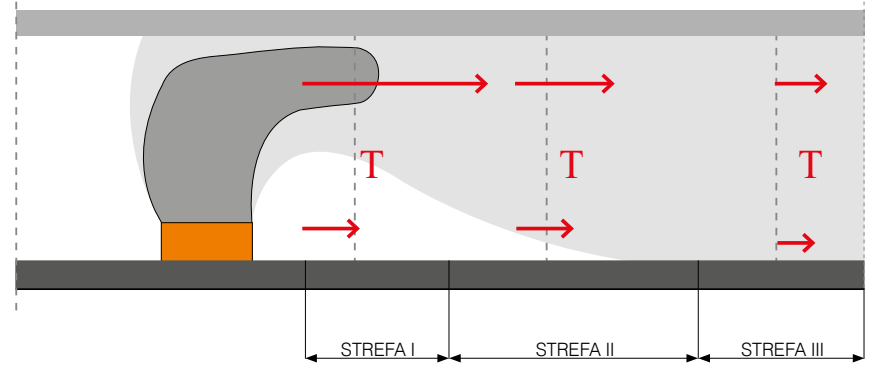

Rycina 5. Podział stref dymowych w tunelu drogowym [3]

Figure 5. Smoke zones in a road tunnel [3]

\section{Zasięg widzialności w dymie}

Określenie parametru widoczności podczas pożarów w tunelach drogowych ma bardzo duży wpływ na bezpieczeństwo użytkowników tego rodzaju obiektów. Obniżenie zasięgu widzenia może utrudniać dotarcie do wyjść ewakuacyjnych lub odnalezienie drogi ucieczki. W najgorszych przypadkach całkowity brak widoczności może również doprowadzić do dezorientacji oraz paniki. W celu oszacowania zasięgu widzialności opracowano specjalne równanie [3]:

$$
V_{s}=\frac{K \cdot \chi}{\ln 10} \frac{u A \Delta H_{c}}{D_{\text {mass }} Q}
$$

gdzie:

$V_{s}$ - widoczność, [m];

$K$ - współczynnik dla światła,

$\chi$ - współczynnik spalania;

$A$ - pole powierzchni tunelu, [m²];

$\Delta H_{c}$ - ciepło spalania, [kJ/kg];

$D_{\text {mass }}$ - masowa gęstość optyczna, $\left[\mathrm{m}^{2} / \mathrm{kg}\right]$;

$Q-$ moc pożaru, [kW];

$u$ - prędkość powietrza w tunelu, [m/s].

Współczynnik (K) jest stały i zależy od sposobu emitowania światła. Wyróżnia się dwa rodzaje emisji światła: poprzez odbicie oraz wydzielanie bezpośrednio przez źródło. Jeżeli źródło odbija światło, to współczynnik $(K)$ przyjmuje wartości od 2 do 4, jeżeli natomiast źródło samodzielnie emituje światło, to współczynnik przyjmuje wartości od 5 do 10.

\section{Określenie rodzaju spalania oraz mocy pożaru}

Podstawowym zagadnieniem podczas odwzorowywania pożarów w tunelach drogowych jest ustalenie rodzaju spalania. Istnieją dwa rodzaje przebiegu reakcji spalania: spalanie kontrolowane przez paliwo oraz spalanie kontrolowane przez wentylację. Do określenia rodzaju spalania wykorzystuje się współczynnik równoważności paliwa do powietrza $\Phi$ [3]

$$
\Phi=\frac{r \dot{m}_{f}}{\dot{m}_{a}}
$$

gdzie:

$\dot{m}_{f}$ - ubytek masy paliwa, [kg/s];

$\dot{m}_{a}$ - masowe natężenie przepływu powietrza, [kg/s];

$r$ - współczynnik stechiometryczny.

\section{Visibility in smoke}

Determining the visibility parameter during fires in road tunnels greatly impacts on the safety of users of such facilities. Reduced visibility may cause difficulties in reaching emergency exits or finding an escape route. In the worst-case scenario, a total lack of visibility poses the risk of confusion and panic. In order to estimate visibility, a special formula was developed [3]:

$$
V_{s}=\frac{K \cdot \chi}{\ln 10} \frac{u A \Delta H_{c}}{D_{\text {mass }} Q}
$$

where:

$V_{s}$ - visibility, [m];

$K$ - rate for light,

$\chi$ - combustion rate;

$A$ - tunnel area, $\left[\mathrm{m}^{2}\right]$;

$\Delta H_{c}$ - heat of combustion, [kJ/kg];

$D_{\text {mass }}$ - mass optical density, $\left[\mathrm{m}^{2} / \mathrm{kg}\right]$;

$Q$ - heat release rate, [kW];

$u$ - air velocity inside the tunnel $[\mathrm{m} / \mathrm{s}]$.

The $(K)$ rate is constant and depends on the manner of light emission. There are two types of light emission: resulting from reflection and coming directly from the source. If the source reflects light, the value of $(K)$ ranges from 2 to 4 , and if the source emits light, the rate is from 5 to 10 .

\section{Determining the type of combustion and the heat release rate}

The fundamental issue when modelling fires in road tunnels is to determine the type of combustion. There are two types of combustion reactions, i.e., fuel-controlled combustion and ventilation-controlled combustion. In order to determine the type of combustion, the fuel-air equivalence ratio is used $\Phi$ [3]:

$$
\Phi=\frac{r \dot{m}_{f}}{\dot{m}_{a}}
$$

where:

$\dot{m}_{f}$ - fuel mass loss, [kg/s];

$\dot{m}_{a}-$ mass flow rate of air, [kg/s];

$r$-stoichiometric ratio. 
W zależności od wartości powyższego współczynnika wyróżnia się dwa rodzaje spalania. Proces kontrolowany przez paliwo występuje wtedy, gdy $\Phi$ jest mniejszy niż 1 . W takim przypadku moc pożaru uzależniona jest od współczynnika ubytku masy. Jest to zależność proporcjonalna i można ją obliczyć na podstawie równania [3]:

$$
Q=\dot{m}_{f} \chi \Delta H_{c}
$$

gdzie:

$\dot{m}_{f}$ - ubytek masy paliwa, [kg/s];

$\chi$ - współczynnik spalania;

$\Delta H_{c}$ - całkowite ciepło spalania netto, [kJ/kg].

Efektywne ciepło spalania $\left(\Delta H_{c, e f f}\right)$ podczas pożarów nigdy nie będzie równe $\Delta H_{c}$. Całkowite ciepło spalania netto musi zostać skorygowane o pewien współczynnik, a dokładnie współczynnik spalania $\chi$. Można go opisać za pomocą następującego wzoru [3]:

$$
\chi=\frac{\Delta H_{c, e f f}}{\Delta H_{c}}
$$

gdzie:

$\Delta H_{c, e f f}$ - efektywne ciepło spalania, [kJ/kg];

$\Delta H_{c}$ - całkowite ciepło spalania netto, [kJ/kg].

Pożar sterowany wentylacją występuje wtedy, gdy $\Phi$ jest większy niż 1. Od masowego natężenia przepływu powietrza zależy proporcjonalnie moc pożaru. Zależność tę opisuje następujące równanie [3]:

$$
Q=\dot{m}_{a} \frac{\Delta H_{c}}{r}
$$

gdzie:

$\dot{m}_{a}$ - masowe natężenie przepływu powietrza, [kg/s];

$r$ - współczynnik stechiometryczny;

$\Delta H_{c}$ - całkowite ciepło spalania netto [kJ/kg].

Maksymalna moc pożaru to bardzo ważny parametr. Najlepsze dane uzyskuje się na podstawie badań w skali 1:1. Aby oszacować maksymalne $Q$ [MW], można zastosować wyrażenie (17). Zależność tę należy stosować wyłącznie do pożarów, które nie są kontrolowane przez wentylację [3]:

$$
\begin{gathered}
Q_{\max }=\sum_{i} \min \left(1,85 \dot{m}_{a} \sum_{i} \frac{\chi_{r, i} \Delta H_{c, i}}{L_{g, i}} ; m_{f, \max , i} A_{f, i} \Delta H_{c, i}\right) \\
\chi_{r, i}=\chi_{r} \frac{A_{i}}{A_{t}} \\
\dot{m}_{a}=0,5 \sum_{i} A_{0, i} H_{0, i}^{1 / 2}
\end{gathered}
$$

gdzie:

$\dot{m}_{a}$ - maksymalne masowe natężenie przepływu powietrza, [kg/s];

$A_{i}-$ i-ta powierzchnia, [m²];

$A_{t}$ - całkowita powierzchnia, suma wszystkich powierzchni $A_{i},\left[\mathrm{~m}^{2}\right]$;

$A_{0, i}$ - i-ta powierzchnia otwartej przestrzeni, [m²];

$H_{0, i}$ - i-ta wysokość otwartej przestrzeni, [m];

$\chi_{r}$ - ułamek ciepła pochłonięty przez powierzchnie;

$\chi_{r, i}$ - ułamek ciepła pochłonięty przez i-tą powierzchnie;

$L_{g}$ - ciepło pirolizy, [MJ/kg];

$\Delta H_{c, i}$ - ciepto spalania, [MJ/kg];
Depending on this ratio, there are two types of combustion. Fuel-controlled combustion takes place when $\Phi$ is lower than 1. In such a case, the heat release rate depends on the mass loss rate. This forms a proportional relationship and can be calculated based on equation [3]:

$$
Q=\dot{m}_{f} \chi \Delta H_{c}
$$

where:

$\dot{m}_{f}$ - fuel mass loss, [kg/s];

$\chi$ - combustion rate;

$\Delta H_{c}$ - total net heat of combustion [kJ/kg].

Effective heat of combustion $\left(\Delta H_{c, e f f}\right)$ never equals $\Delta H_{c}$ during a fire. The total net heat of combustion must be adjusted for the combustion rate $\chi$. It can be described using the following formula [3]:

$$
\chi=\frac{\Delta H_{c, e f f}}{\Delta H_{c}}
$$

where:

$\Delta H_{c, e f f}$ - effective heat of combustion, [kJ/kg];

$\Delta H_{c}-$ total net heat of combustion, [kJ/kg].

A ventilation-controlled fire takes place when $\Phi$ is greater than 1 . The heat release rate is proportional to the mass flow rate of air. This relationship is described by the following formula [3]:

$$
Q=\dot{m}_{a} \frac{\Delta H_{c}}{r}
$$

where:

$\dot{m}_{a}$ - mass flow rate of air $[\mathrm{kg} / \mathrm{s}]$;

$r$ - stoichiometric ratio;

$\Delta H_{c}$ - total net heat of combustion [kJ/kg].

The maximum heat release rate is a crucial parameter. The best data are obtained based on 1:1 tests. In order to estimate maximum $Q[\mathrm{MW}]$, one can use expression (17). This relationship should be applied only to those fires which are not ventilation-controlled.

$$
\begin{gathered}
Q_{\max }=\sum_{i} \min \left(1.85 \dot{m}_{a} \sum_{i} \frac{\chi_{r, i} \Delta H_{c, i}}{L_{g, i}} ; m_{f, \max , i} A_{f, i} \Delta H_{c, i}\right) \\
\chi_{r, i}=\chi_{r} \frac{A_{i}}{A_{t}} \\
\dot{m}_{a}=0.5 \sum_{i} A_{0, i} H_{0, i}^{1 / 2}
\end{gathered}
$$

where:

$\dot{m}_{a}$ - maximum mass flow rate of air, [kg/s];

$A_{i}-\mathrm{i}$-th area, $\left[\mathrm{m}^{2}\right]$

$A_{t}$ - total area, the sum of all areas $A_{i^{\prime}}\left[\mathrm{m}^{2}\right]$;

$A_{0, i}-\mathrm{i}$-th area of an open space, $\left[\mathrm{m}^{2}\right]$;

$H_{0, i}$ - i-th height of an open space, [m];

$\chi_{r}-$ fraction of heat absorbed by the area;

$\chi_{r, i}-$ fraction of heat absorbed by the i-th area;

$L_{g}$ - heat of pyrolysis, [MJ/kg];

$\Delta H_{c, i}$ - heat of combustion, [MJ/kg]; 


\section{Badania numeryczne}

Program komputerowy Fire Dynamics Simulator (FDS) został stworzony przez amerykański instytut National Institute of Standards and Technology (NIST) jako aplikacja wykorzystywana do modelowania pożarów za pomocą numerycznej dynamiki płynów (CFD). Program bazuje na rozwiązywaniu uproszczonego układu równań Naviera-Stokes'a dla prędkości przepływu mniejszej lub równej $102 \mathrm{~m} / \mathrm{s}$. Program został opracowany, aby ułatwić pracę inżynierom i specjalistom zajmującym się bezpieczeństwem pożarowym. FDS umożliwia modelowanie rozwoju pożaru oraz analizę zjawisk towarzyszących pożarom w geometriach prostych oraz złożonych. Program FDS wykorzystuje modele fizyczne zjawisk do opisu pożaru. Głównymi modelami numerycznymi są w tym przypadku: model hydrodynamiczny, model spalania, model promieniowania cieplnego. Fire Dynamics Simulator wykorzystuje również takie moduły jak: geometria i budowa siatek wielokrotnych, obliczenia równoległe oraz warunki brzegowe [4-5]. Pomimo złożoności programu FDS, posiada on pewne ograniczenia. Jednym z głównych utrudnień jest założenie wolnego przepływu, czyli wartości prędkości mniejszej lub równej około $102 \mathrm{~m} / \mathrm{s}$, co stanowi barierę w stosowaniu programu w badaniu i poznawaniu procesów takich jak eksplozje. Zastosowanie w programie geometrii prostoliniowej komplikuje odwzorowanie różnych powierzchni nieprzecinających się pod kątem 90 stopni. Rozwiązaniem tego problemu jest maksymalne zagęszczenie siatki obliczeniowej oraz możliwie najwierniejsze odwzorowanie elementu za pomocą dostępnych metod. Dzięki takiemu zabiegowi możliwe jest zaprojektowanie powierzchni lub obiektu maksymalnie przypominającego obiekt rzeczywisty. Do wykonania symulacji z jak największą dokładnością musi być znana ściśle określona szybkość wydzielania się ciepła (HRR). W przypadku gdy szybkość wydzielania ciepła jest nieznana, otrzymane wyniki obarczone będą większą niedokładnością. W programie FDS wykorzystywane są modele empiryczne, które zwiększają dokładność wyników podczas symulacji w pomieszczeniach słabo wentylowanych oraz w pomieszczeniach, gdzie znajduje się dużo pary wodnej lub dwutlenku węgla. W programie zostało wykorzystane równanie Radiation Transport Equation (RTE), które opisuje radiacyjną wymianę ciepła dla gazu szarego. Jest ono rozwiązywane metodą Finie Volume Metod (FVM), czyli metodą objętości kontrolnych. Wykorzystanie tego modelu jest rozwiązaniem niedoskonałym ze względu na radiację strumienia na obiekty odległe od źródła promieniowania. Dodatkowo sadza może zaburzać emisję promieniowania cieplnego [4]. Do wizualizacji danych wyjściowych, otrzymanych w wyniku symulacji, wykorzystywany jest program Smokeview. Program w animowany sposób przedstawia zjawiska pożarowe, takie jak przepływ dymu, rozprzestrzenianie się pożaru, płomień, kierunki rozchodzenia się temperatury itp. Za pomocą Smokeview można również pokazać wykresy i kierunki wektorów, np. prędkości przepływu dymu lub ciepła. Co więcej aplikacja umożliwia bieżące kontrolowanie postępów w przygotowywanej symulacji poprzez wyświetlanie obrazu podczas wprowadzania danych wejściowych. Dzięki temu można dokonywać weryfikacji oraz wprowadzać poprawki

\section{Numerical studies}

The Fire Dynamics Simulator (FDS) software was developed by the National Institute of Standards and Technology (NIST) to model fires using computational fluid dynamics (CFD). The software is based on a simplified Navier-Stokes equations system for flow velocities less than or equal to $102 \mathrm{~m} / \mathrm{s}$. It was designed to streamline the work of fire safety engineers and specialists. FDS makes it possible to model fire development, and to analyse fire phenomena in simple and complex geometries. It utilises physical models of phenomena to describe fires. In this case, the main numerical models are the hydrodynamic model, the combustion model, and the thermal radiation model. The Fire Dynamics Simulator also uses such modules as the multiple mesh geometry and structure, parallel computing, and boundary conditions [4-5]. Despite its complexity, FDS has some limitations. One of the main difficulties is the assumption of free flow, i.e. a velocity which is less than or equal to about $102 \mathrm{~m} / \mathrm{s}$, which constitutes a barrier to using the programme in studying and learning about selected processes, such as explosions. The use of rectilinear geometry in the programme makes it complicated to represent surfaces which do not intersect at 90 degrees. To address this problem, one can increase the density of the grid to the maximum, and represent the element using the available methods as precisely as possible. This makes it possible to design areas or objects which resemble the actual ones as close as possible. To perform the simulation with the greatest possible accuracy, one must know a precisely defined heat release rate (HRR). When the heat release rate is unknown, the obtained results can be subject to greater inaccuracy. FDS uses empirical models which increase the accuracy of the results during simulation in poorly ventilated rooms and in rooms with significant amounts of water vapour or carbon dioxide. The programme also uses the Radiation Transport Equation (RTE) which describes radiative heat transfer for a grey gas. It is solved using the Finite Volume Method (FVM). The application of this model is an imperfect solution because of the radiant flux affecting objects located far away from the radiation source. In addition, soot can disturb the emission of thermal radiation [4]. In order to visualize the output data resulting from simulations, the Smokeview programme is used. It animates fire phenomena such as smoke flow, fire propagation, flame, directions of temperature propagation, etc. Also, Smokeview can be used to display graphs and directions of vectors, for example, of smoke flow velocity or heat. Furthermore, the app makes it possible to control the prepared simulation progress on an ongoing basis by displaying images while the input data are being entered. This allows verification and correction to be performed at the modelling stage. Visualising fire phenomena provides great opportunities for improving safety in various facilities. Evacuation of people is among its most significant aspects. The knowledge of the distribution of smoke layers and the time of their movement makes it is easy to plan the evacuation of users from a building or a non-building structure [4]. 
na etapie modelowania. Używanie wizualizacji zjawisk pożarowych daje duże możliwości poprawy bezpieczeństwa w obiektach. Jednym z bardziej znaczących aspektów jest ewakuacja ludzi. Dzięki znajomości rozkładu warstw dymu oraz czasu ich przemieszczania się, w łatwy sposób można zaplanować ewakuację użytkowników z budynku lub budowli [4].

Badania numeryczne przeprowadzono w programie PyroSim [5], na podstawie danych doświadczalnych w dużej skali podczas rzeczywistego pożaru testowego w tunelu Runehamar w Norwegii [3]. Wszystkie symulacje wykonano na siatce obliczeniowej o wymiarach $208 \times 7 \times 5 \mathrm{~m}$. Pojedyncza komórka siatki obliczeniowej miała kształt sześcianu foremnego o wymiarach 0,5 m. Łącznie komórek obliczeniowych było 58240 . W badaniach wykorzystany został model tunelu przedstawiony na rycinie poniżej. Całkowita długość tunelu wynosiła $200 \mathrm{~m}$, szerokość otworów wlotowego i wylotowego $7 \mathrm{~m}$, natomiast wysokość otworów $5 \mathrm{~m}$. Ściany nie zostały zamodelowane jako przeszkody. Do tego celu została wykorzystana siatka obliczeniowa. W tunelu znajdowały się dwa wentylatory wyciągowe umieszczone pod sufitem w odległościach 52,5 i 152,5 m od otworu wlotowego do tunelu. Dystans pomiędzy urządzeniami a osią tunelu wynosił 2,25 m. Powierzchnia otworów, w których zasysano powietrze oraz dym z prędkością $3 \mathrm{~m} / \mathrm{s}$, równała się $1 \mathrm{~m}^{2}$. Dodatkowo została utworzona powierzchnia, która miała za zadanie wytworzenie przepływu powietrza w tunelu o prędkości $2 \mathrm{~m} / \mathrm{s}$. W drugim otworze wylotowym granice siatki zostały otwarte. Dzięki temu umożliwiono swobodny wypływ dymu z tunelu. Źródło pożaru o wymiarach $4 \times 2 \times 1 \mathrm{~m}$ znajdowało się w odległości $100 \mathrm{~m}$ od wlotu do tunelu. Na tej przeszkodzie utworzono went, który symulował pożar o powierzchni $8 \mathrm{~m}^{2}$.
Numerical studies were conducted in the PyroSim [5] programme, based on large-scale experimental data during an actual fire test in the Runehamar Tunnel in Norway [3]. All simulations were performed on a grid of $208 \times 7 \times 5 \mathrm{~m}$. A single grid cell was a $0.5 \mathrm{~m}$ cube. There were 58,240 such cells in total. The tunnel model presented in the figure below was used in the studies. The total tunnel length was $200 \mathrm{~m}$, the width of the inlet and outlet was $7 \mathrm{~m}$, and their height equalled $5 \mathrm{~m}$. The walls were not modelled as obstacles. A grid was used for this purpose. In the tunnel, there were two exhaust fans located under the ceiling at a distance of 52.5 and $152.5 \mathrm{~m}$ from the tunnel inlet. The distance between the devices and the tunnel axis was $2.25 \mathrm{~m}$. The surface of openings in which air and smoke was sucked in with a velocity of $3 \mathrm{~m} / \mathrm{s}$ was $1 \mathrm{~m}^{2}$. In addition, a surface was established to create an airflow inside the tunnel with a velocity of $2 \mathrm{~m} / \mathrm{s}$. In the second outlet, the grid borders were opened. This facilitated the free flow of smoke in the tunnel. The source of the fire, with the dimensions of $4 \times 2 \times 1 \mathrm{~m}$, was located $100 \mathrm{~m}$ from the tunnel inlet. A vent was created on this obstacle, which simulated a fire with an area of $8 \mathrm{~m}^{2}$.
Rycina 6. Widok ogólny tunelu

Figure 6. General view of the tunnel

Moc pożaru była zależna od realizowanego podczas obliczeń scenariusza rozwoju pożaru. W symulacji wykorzystano funkcję HRRPUA, którą opisano szybkość spalania masy na jednostkę powierzchni. Wartości zostały zaczerpnięte z danych doświadczalnych [3]. Do testów wykorzystano cztery moce pożarów podane $w$ tabeli 6 . Parametry pożaru, takie jak temperatura czy prędkość przepływu powietrza, zmierzono za pomocą urządzeń do pomiaru fazy gazowej. Termoelementy zostały umieszczone na dwóch wysokościach, tj. na wysokości: 1,8 m oraz 4,7 m. Urządzenia do pomiaru prędkości przepływu powietrza umieszczono nad źródłem na wysokościach 1,8, 3,25 oraz 4,7 m. Odległości urządzeń od początku tunelu zaprezentowano
The heat release rate depended on the fire development scenario implemented during the calculations. The HRRPUA function was used in the simulation, describing the mass combustion rate per unit area. The values were taken from experimental data [3]. The four heat release rates given in Table 6 were used in the tests. Fire parameters, such as temperature and airflow velocity, were measured using gaseous phase measurement equipment. Thermocouples were positioned at heights of $1.8 \mathrm{~m}$ and $4.7 \mathrm{~m}$. Airflow velocity measurement devices were positioned above the source, at heights of $1.8,3.25$ and $4.7 \mathrm{~m}$. The distances between the devices and the tunnel entrance are presented in Figure 7. Centimetre is the basic unit in the fig- 
na rycinie 7. Na rycinach opisujących geometrię tunelu podstawową jednostką był centymetr. Natomiast na rycinie 7 w nawiasach podano odległości urządzeń od centrum pożaru wyrażone w metrach. W celu łatwej orientacji w rozmieszczeniu poszczególnych urządzeń znajdujących się przed źródłem wprowadzono znak "-" poprzedzający wartość odległości wyrażoną liczbowo. Podobnie postąpiono w przypadku termopar znajdujących się za centrum pożaru - wykorzystując znak " + ". ures describing tunnel geometry. In turn, Figure 7 displays (in brackets) the distances between the devices and the fire centre in metres. For the ease of orientation in the arrangement of individual devices located ahead of the source, the "-" sign was introduced before the numerical value of the distance. Thermocouples located behind the fire source were marked in a similar fashion, with the "+" sign.

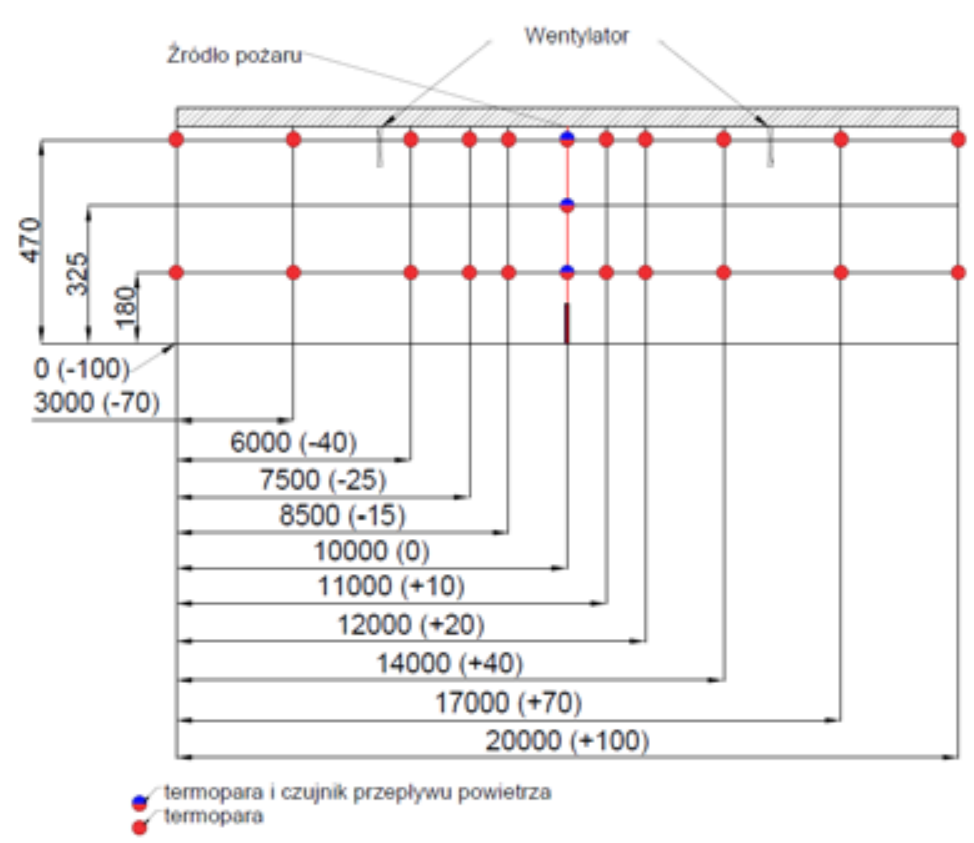

Rycina 7. Schemat rozmieszczenia urządzeń pomiarowych

Figure 7. Locations of measurement equipment

W celu wizualizacji wyników na modelu zostało utworzonych sześć płaszczyzn wynikowych. Trzy z nich dotyczyły temperatury, dwie widoczności i jedna prędkości przepływu powietrza. Dokładny opis płaszczyzn oraz położenie w geometrii pokazują rycina 8 oraz tabela 1.
To visualise the results, six result planes were superimposed on the model. Three of these concerned temperature, two related to visibility, and one to airflow velocity. A detailed description of the planes and their positioning in the model geometry is shown in Figure 8 and Table 1.

Tabela 1. Właściwości płaszczyzn wynikowych

Table 1. A set of results

\begin{tabular}{cccc}
\hline & Płaszczyzna XYZ / XYZ plane & Wartość płaszczyzny / Plane's value & Wielkość fazy gazowej / Gas phase value \\
\hline 1 & $Y$ & $5,0 \mathrm{~m} / 5.0 \mathrm{~m}$ & Temperatura / Temperature \\
\hline 2 & $\mathrm{Z}$ & $1,8 \mathrm{~m} / 1.8 \mathrm{~m}$ & Temperatura / Temperature \\
\hline 3 & $\mathrm{Z}$ & $1,8 \mathrm{~m} / 1.8 \mathrm{~m}$ & Widoczność / Visibility \\
\hline 4 & $\mathrm{Y}$ & $2,75 \mathrm{~m} / 2.75 \mathrm{~m}$ & Prędkość / Velocity \\
\hline 5 & $\mathrm{Y}$ & $5,0 \mathrm{~m} / 5.0 \mathrm{~m}$ & Widoczność / Visibility \\
\hline 6 & $\mathrm{Z}$ & $4,7 \mathrm{~m} / 4.7 \mathrm{~m}$ & Temperatura / Temperature \\
\hline
\end{tabular}

Źródło: Opracowanie własne.

Source: Own elaboration.

Rycina 8 przedstawia ułożenie płaszczyzn na modelu. Kolorem żółtym zaznaczono płaszczyzny wynikowe. W jej lewym dolnym rogu znajduje się układ odniesienia. Długość tunelu została zorientowana wzdłuż osi "X”, szerokość wzdłuż osi „Y”,
Figure 8 presents the arrangement of the planes on the model. The result planes are yellow. A frame of reference can be seen in the bottom left corner. The length, width and height of the tunnel were oriented along the " $X$ ", " $Y$ " and " $Z$ " axes, re- 
natomiast wysokość wzdłuż osi „Z”. Wlot tunelu znajdował się dokładnie na początku układu współrzędnych. Dzięki temu w prosty sposób można było określić odległości od poszczególnych obiektów. spectively, and the tunnel inlet was positioned exactly at the beginning of the coordinate system. This made it possible to easily determine the distances to individual objects.

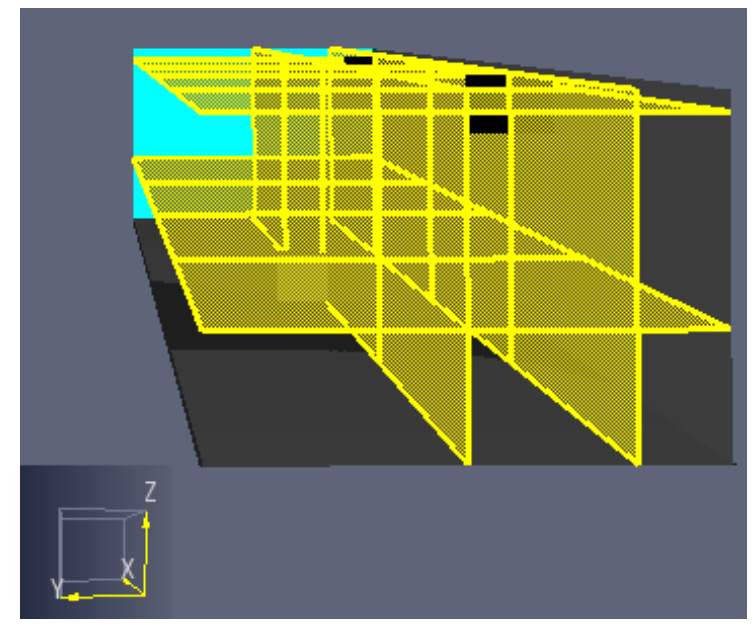

Rycina 8. Położenie płaszczyzn wynikowych na modelu

Figure 8. Result areas displayed in the model

\section{Charakterystyka tunelu Runehamar}

W tunelu Runehamar przeprowadzono badania eksperymentalne pożarów w dużej skali. Pomogły one zrozumieć zagadnienia związane z pożarami w tego typu obiektach [3]. W próbach tych starano się jak najlepiej odwzorować materiał palny, który może znajdować się w tunelu przy jego zwykłej eksploatacji. Wykonano łącznie cztery testy z wykorzystaniem głównie drewna, materiałów z tworzyw sztucznych, materacy (PUR'), jak również mebli i materiałów gumowych.

\section{The Runehamar Tunnel characteristics}

Large-scale experimental fire tests were carried out in the Runehamar Tunnel. The tests allowed people to better understand the issues related to fires in such structures [3]. Attempts were made to reproduce, as accurately as possible, the combustible material that may be present in the tunnel during its normal use. Four tests in total were carried out using mainly wood, plastic materials, mattresses $\left(P U R^{1}\right)$, as well as furniture and rubber materials.

Tabela 2. Materiały użyte podczas testów Runehamar [3]

Table 2. Materials used in the Runehamar experiments [3]

\begin{tabular}{llcc}
\hline $\begin{array}{c}\text { Numer testu } \\
\text { / Test No. }\end{array}$ & \multicolumn{1}{c}{$\begin{array}{c}\text { Opis } \\
\text { / Description }\end{array}$} & $\begin{array}{c}\text { Masa całkowita } \\
\text { / Total mass [kg] }\end{array}$ & $\begin{array}{c}\text { Udział materiałów z tworzyw sztucznych } \\
\text { / Percentage of plastic materials [\%] }\end{array}$ \\
\hline Test 1 & Palety drewniane oraz polietylenowe / Wooden and polyethylene pallets & 11010 & 18 \\
\hline Test 2 & $\begin{array}{l}\text { Palety drewniane materace poliuretanowe } \\
\text { / Woooden pallets, polyurethane mattresses }\end{array}$ & 6930 & 18 \\
\hline Test 3 & $\begin{array}{l}\text { Meble i opony } \\
\text { / Furniture and tyres }\end{array}$ & 8550 & 18 (brak opon / no tyres) \\
\hline \multirow{2}{*}{ Test 4} & $\begin{array}{l}\text { Kubki polistyrenowe w pudełkach kartonowych umieszczone na drewnia- } \\
\text { nych paletach } \\
\text { / Polystyrene cups in cardboard boxes, on wooden pallets }\end{array}$ & 2850 \\
\hline
\end{tabular}

Na potrzeby testów w tunelu Runehamar zastosowano specjalną konstrukcję wewnętrznego tunelu z płyt ogniochronnych. Tunel Runehamar ma 1,6 km długości, 6 m wysokości oraz 9 m szerokości. Stworzona konstrukcja miała około $75 \mathrm{~m}$ długości, 7,1 m szerokości oraz $5 \mathrm{~m}$ wysokości. Składała się z płyt PROMATECT-T o grubości od 45 do $25 \mathrm{~mm}$. Najgrubsze płyty zostały umieszczone przy źródle pożaru. W tak skonstruowanym, wewnętrznym tunelu umieszczono przygotowany materiał palny.
For the purposes of the Runehamar Tunnel experiments, a special internal structure made of fireproof cladding was used. The Runehamar Tunnel is $1.6 \mathrm{~km}$ long, $6 \mathrm{~m}$ high, $9 \mathrm{~m}$ wide. The created structure was $75 \mathrm{~m}$ long, $7.1 \mathrm{~m}$ wide and $5 \mathrm{~m}$ high. It was made of PROMATECT-T boards with a thickness ranging from 45 to $25 \mathrm{~mm}$. The thickest boards were placed near the source of the fire. The prepared flammable material was positioned inside the tunnel. 


\section{Przygotowanie symulacji CFD}

Geometria tunelu została odwzorowana na podstawie publikacji naukowych zawierających szczegółowe opisy badań doświadczalnych w tunelu Runehamar [6]. Jednakże na potrzeby badań numerycznych została ona w znacznym stopniu uproszczona. Przyjęto prostopadłościenny kształt tunelu o długości $200 \mathrm{~m}$, szerokości $7 \mathrm{~m}$ oraz wysokości $5 \mathrm{~m}$. Pole powierzchni otworu wlotowego wynosiło $35 \mathrm{~m}^{2}$. W tunelu Runehamar pole powierzchni otworu wynosiło $32 \mathrm{~m}^{2}$. Przeprowadzono łącznie cztery symulacje komputerowe. Czas pojedynczej symulacji wynosił $900 \mathrm{~s}$ (dla mocy pożaru $202 \mathrm{MW}$ - 1100 sekund). W zależności od scenariusza zastosowano różne moce pożarów(uwzględniając wyniki badań doświadczalnych w tunelu Runehamar) [6]. Czasy osiągnięcia szczytowej szybkości wydzielania ciepła również nie były jednakowe. Stałe wartości pojawiające się w każdej symulacji to: prędkość powietrza w tunelu oraz prędkość powietrza zasysanego przez dwa wentylatory umieszczone pod sufitem.

\section{Preparing CFD simulation}

The tunnel geometry was modelled on research papers presenting detailed descriptions of experimental tests in the Runehamar Tunnel [6]. It was, however, significantly simplified for the purposes of numerical studies. It was assumed that the tunnel was cuboidal in shape, $200 \mathrm{~m}$ long, $7 \mathrm{~m}$ wide and $5 \mathrm{~m}$ high. The area of the inlet was $35 \mathrm{~m}^{2}$. In the Runehamar Tunnel, this area equalled $32 \mathrm{~m}^{2}$. In total, four computer simulations were conducted. The time of one simulation was $900 \mathrm{~s}$ (for a heat release rate of $202 \mathrm{MW}-1100$ seconds). Depending on the scenario, various heat release rates were applied (taking into account the experimental tests carried out in the Runehamar Tunnel) [6]. The times of reaching the peak heat release rate were also not the same. The constant values which appeared in every simulation included the velocity of air in the tunnel and the velocity of air sucked in by the two fans located under the ceiling.

Tabela 3. Podstawowe parametry wykorzystane w symulacjach

Table. 3. Fundamental parameters used in numerical simulations

\begin{tabular}{|c|c|c|c|c|c|}
\hline $\begin{array}{l}\text { Oznaczenie testu } \\
\text { / Test specification }\end{array}$ & $\begin{array}{c}\text { Moc pożaru } \\
\text { / Heat release rate } \\
\text { [MW] }\end{array}$ & $\begin{array}{l}\text { Czas osiągnięcia maksymalnej } \\
\text { mocy pożaru } \\
\text { / Time until reaching the ma- } \\
\text { ximum heat release rate } \\
\text { [min] }\end{array}$ & $\begin{array}{l}\text { Prędkość powietrza } \\
\text { w tunelu } \\
\text { / Air velocity inside } \\
\text { the tunnel } \\
{[\mathrm{m} / \mathrm{s}]}\end{array}$ & $\begin{array}{l}\text { Prędkość powietrza } \\
\text { z wentylatorów } \\
\text { / Air velocity } \\
\text { generated by fans } \\
{[\mathrm{m} / \mathrm{s}]}\end{array}$ & $\begin{array}{l}\text { Temperatura otoczenia } \\
\text { / Ambient temperature } \\
\left.\text { [ }{ }^{\circ} \mathrm{C}\right]\end{array}$ \\
\hline $\mathrm{T} 2$ & 202 & 18 & 2 & 3 & 12 \\
\hline T2 & 157 & 14 & 2 & 3 & 11 \\
\hline T3 & 119 & 10 & 2 & 3 & $9,5 / 9.5$ \\
\hline $\mathrm{T} 4$ & 67 & 14 & 2 & 3 & 11 \\
\hline
\end{tabular}

Dodatkowo - na podstawie wzorów zawartych w publikacjach naukowych - przeprowadzono również obliczenia matematyczne w celu porównania wartości parametrów uzyskanych dzięki symulacji oraz badań doświadczalnych przeprowadzonych w tunelu Runehamar. Podczas obliczeń wykorzystano dane literaturowe $[3,6]$.

\section{Obliczenie mocy pożaru}

Na podstawie równania (14) obliczono maksymalną moc pożaru, wykorzystując dane zawarte w tabeli 4 . Skład materiałowy pożarów testowych został przyjęty z tabeli 2 .
In addition, based on the formulas presented in scientific publications, mathematic calculations were performed to compare the values of parameters obtained through simulation and experimental tests carried out in the Runehamar Tunnel. Data found in the literature $[3,6]$ were used in the calculations.

\section{Calculating the heat release rate}

Using formula (14), the maximum heat release rate was calculated, based on the data presented in Table 4. The material composition of the test fires was taken from Table 2.

Tabela 4. Maksymalna szybkość wydzielania ciepła

Table 4. Maximum heat release rate

\begin{tabular}{|c|c|c|c|c|c|c|c|}
\hline $\begin{array}{l}\text { Nazwa } \\
\text { / Name }\end{array}$ & $\begin{array}{c}\text { Materiał } \\
\text { / Material }\end{array}$ & $\begin{array}{c}\text { Ilość / Quantity } \\
\text { [\%] }\end{array}$ & $\stackrel{\text { A }}{[\mathrm{m} 2]}$ & $\dot{m}_{f}$ & $\begin{array}{c}\Delta H_{c} \\
{[\mathbf{M J} / \mathbf{k g}]}\end{array}$ & $x$ & $\begin{array}{c}Q \\
{[\mathrm{MW}]}\end{array}$ \\
\hline \multirow{2}{*}{$\mathrm{T} 1$} & drewno / wood & 82 & 1024 & $0,013 / 0.13$ & $16,7 / 16.7$ & $0,9 / 0.9$ & \multirow{2}{*}{$265,3 / 265.3$} \\
\hline & materiały polietylenowe / polyethylene materials & 18 & 1024 & $0,014 / 0.014$ & $43,6 / 43.6$ & $0,9 / 0.9$ & \\
\hline \multirow{2}{*}{ T2 } & drewno / wood & 82 & 607 & $0,013 / 0.013$ & $16,7 / 16.7$ & $0,9 / 0.9$ & \multirow{2}{*}{$175,9 / 175.9$} \\
\hline & materace poliuretanowe / polyurethane mattresses & 18 & 607 & $0,032 / 0.032$ & 25 & $0,9 / 0.9$ & \\
\hline T3 & meble / furniture & 100 & 268 & $0,02 / 0.02$ & 25 & $0,9 / 0.9$ & $120,6 / 120.6$ \\
\hline \multirow{2}{*}{ T4 } & drewno / wood & 81 & 195 & $0,013 / 0.013$ & $16,7 / 16.7$ & $0,9 / 0.9$ & \multirow{2}{*}{$60,0 / 60.0$} \\
\hline & kubki polistyrenowe / polystyrene cups & 19 & 195 & $0,035 / 0.035$ & 25 & $0,9 / 0.9$ & \\
\hline
\end{tabular}


Wyniki otrzymane z testów w tunelu Runehamar odpowiadają wynikom uzyskanym za pomocą równań matematycznych. Różnice pomiędzy nimi wynoszą około $31 \%$, co potwierdza możliwość ich dalszego zastosowania do innych tuneli.
The results following the tests in the Runehamar Tunnel correspond to those resulting from mathematical equations. The differences amounted to approx. $31 \%$, which confirms the possibility of their further application in relation to other tunnels.

Tabela 5. Dane wykorzystane do obliczenia maksymalnej szybkości wydzielania ciepła

Table 5. Data used in the calculation of the maximum heat release rate

\begin{tabular}{lcc}
\hline \multicolumn{1}{c}{ Materiał / Material } & $\begin{array}{c}\text { Ubytek masy paliwa na jednostkę powierzchni } \\
\text { / Fuel mass loss per unit area } \\
{\left[\mathbf{k g} / \mathbf{m}^{2} \mathbf{s}\right]}\end{array}$ & $\begin{array}{c}\text { Ciepło spalania } \\
\text { Heat of combustion } \\
{[\mathbf{M J} / \mathbf{k g}]}\end{array}$ \\
\hline Olej napędowy / Diesel fuel & $0,035 / 0.035$ & $39,7 / 39.7$ \\
\hline Drewno / Wood & $0,013 / 0.013$ & $16,7 / 16.7$ \\
\hline Materiały polietylenowe / Polyethylene materials & $0,014 / 0.014$ & $43,6 / 43.6$ \\
\hline Materiały poliuretanowe / Polyurethane materials & $0,032 / 0.032$ & $25,0 / 25.0$ \\
\hline Meble / Furniture & $0,020 / 0.020$ & $25,0 / 25.0$ \\
\hline
\end{tabular}

\section{Wyniki symulacji}

Na podstawie zebranych danych z urządzeń pomiarowych umieszczonych na wysokościach 1,8 i 4,7 m wykonano wykresy zależności temperatury od czasu. Pod uwagę wzięto odległość termoelementów od źródła pożaru. Należy również zwrócić uwagę, że każde badanie osiągało maksymalną szybkość wydzielania ciepła w innym czasie. W związku z tym konieczne jest rozpatrywanie indywidualnie każdej krzywej.

\section{Simulation results}

Based on the data collected from measurement devices located at heights of $1.8 \mathrm{~m}$ and $4.7 \mathrm{~m}$, temperature-to-time relation charts were drawn up. The distance between the thermocouples and the fire source was taken into account. It should also be noted that the maximum heat release rate was obtained in every test at different times. Therefore, it is necessary to analyse every curve individually.

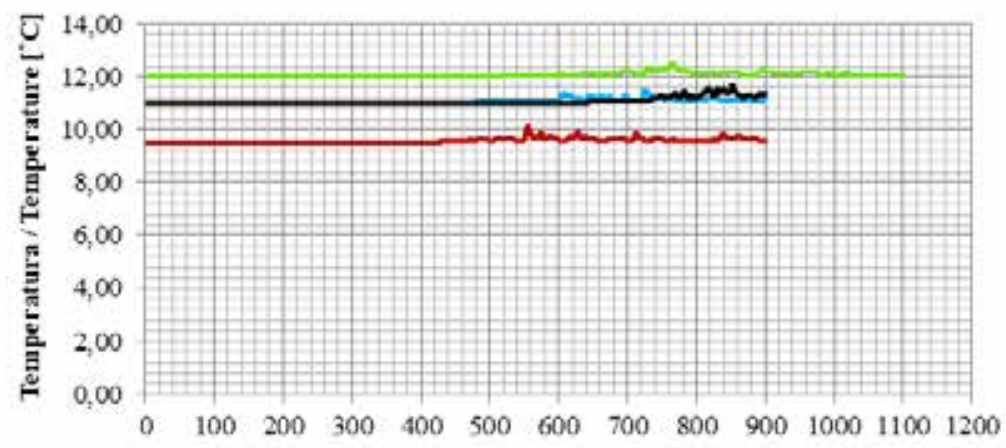

-202 MW Czas / Time [s]

Rycina 9. Pomiar temperatury w odległości 70 metrów przed źródłem pożaru i na wysokości 1,8 m od poziomu podłogi

Figure 9. Temperature at a distance of $70 \mathrm{~m}$ ahead of the fire source and at a height of $1.8 \mathrm{~m}$ above the floor

Na rycinie 9 wyraźnie widać, że w całym zakresie badania temperatura powietrza oraz gazów pożarowych w odległości około 70 metrów przed źródłem pożaru i na wysokości 1,8 metra oscylowała w granicach temperatury początkowej. Przy mocach pożarów $202 \mathrm{MW}$ oraz $157 \mathrm{MW}$ minimalne wahania temperatury rozpoczynają się po około 600 sekundach. W pożarze o najmniejszej mocy niewielkie zmiany temperatury zachodziły po około 800 sekundach, natomiast w badaniu T3 - po 450 sekundach.

W odległościach $40,25,15 \mathrm{~m}$ przed źródłem pożaru temperatura nie przekraczała $23^{\circ} \mathrm{C}$. Wzrost temperatury w badaniach T1 i T2 rozpoczął się po około 250 sekundach. Przy mocy pożaru wynoszącej $67 \mathrm{MW}$ zmiana temperatury rozpoczęła się po 350 sekundach. Utrzymywanie się tak niskiej temperatury było spowodowane oddziaływaniem wzdłużnego przepły-
Figure 9 clearly shows that throughout the entire scope of the test, the air and fire gases temperatures at a distance of approx. 70 metres ahead of the fire source, as well as at a height of $1,8 \mathrm{~m}$, were close to the initial temperature. With the heat release rates of $202 \mathrm{MW}$ and $157 \mathrm{MW}$, the minimum temperature fluctuations started after about 600 seconds. As regards the fire with the weakest heat release rate, temperature changes were recorded after approx. 800 seconds, while in T3, after 450 seconds.

At the distances of 40,25 , and $15 \mathrm{~m}$ ahead of the fire source, temperature did not exceed $23^{\circ} \mathrm{C}$. It started to increase in $\mathrm{T} 1$ and $\mathrm{T} 2$ after about 250 seconds. When the heat release rate equalled $67 \mathrm{MW}$, temperature started to change after 350 seconds. The fact that temperature remained at such a low level was due to the longitudinal airflow. The movement of air with a velocity of $2 \mathrm{~m} / \mathrm{s}$ prevents any increase in temperature at a height of $1,8 \mathrm{me}-$ 


\section{FIRE ENGINEERING}

wu powietrza. Ruch powietrza o prędkości $2 \mathrm{~m} / \mathrm{s}$ uniemożliwia wzrost temperatury na wysokości 1,8 m nad poziomem podłogi. Dodatkowo gorące gazy pożarowe pod wpływem sił wyporu samoistnie unosiły się do góry. Należy pamiętać, że w badaniach przyjęto różne temperatury początkowe. W związku z tym, przy tak niewielkich zmianach temperatur występowały minimalne różnice wartości maksymalnych pomiędzy krzywymi. tres above the floor. In addition, hot fire gases were raised spontaneously by the buoyant force. One should bear in mind that various initial temperatures were assumed in the tests. Therefore, very slight differences in the maximum values were observed between the curves, with small changes in temperature.

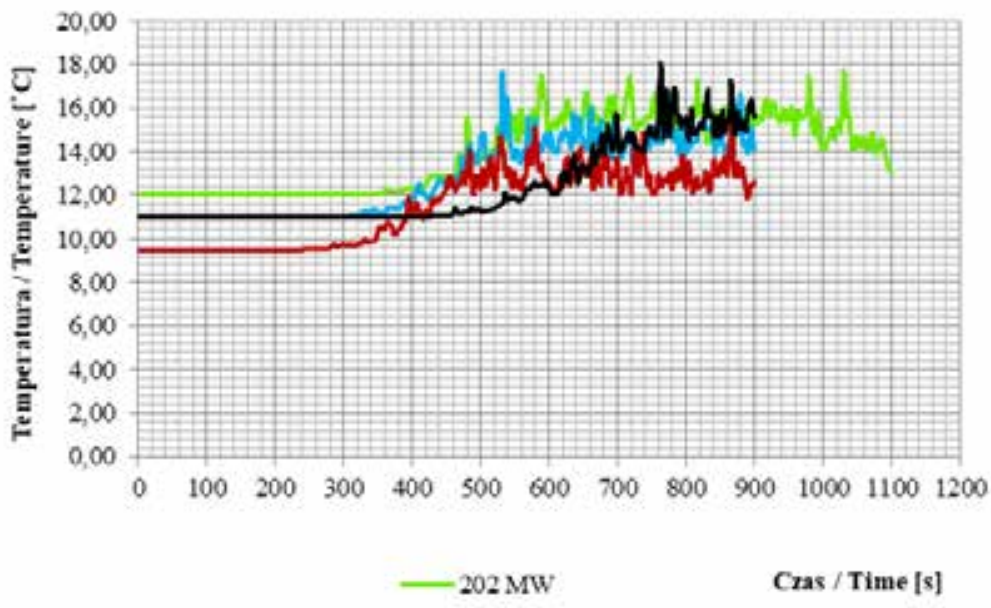

Rycina 10. Pomiar temperatury w odległości $40 \mathrm{~m}$ przed źródłem pożaru i na wysokości 1,8 $\mathrm{m}$ od poziomu podłogi Figure 10. Temperature at a distance of $40 \mathrm{~m}$ ahead of the fire source and at a height of $1.8 \mathrm{~m}$ above the floor

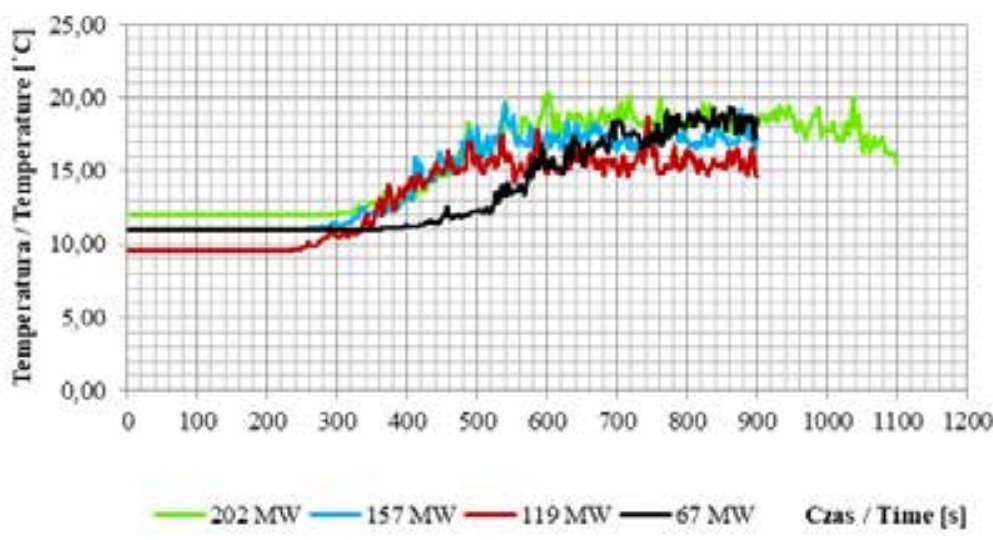

Rycina 11. Pomiar temperatury w odległości $25 \mathrm{~m}$ przed źródłem pożaru i na wysokości 1,8 m od poziomu podłogi Figure 11. Temperature at a distance of $25 \mathrm{~m}$ ahead of the fire source and a height of $1.8 \mathrm{~m}$ above the floor

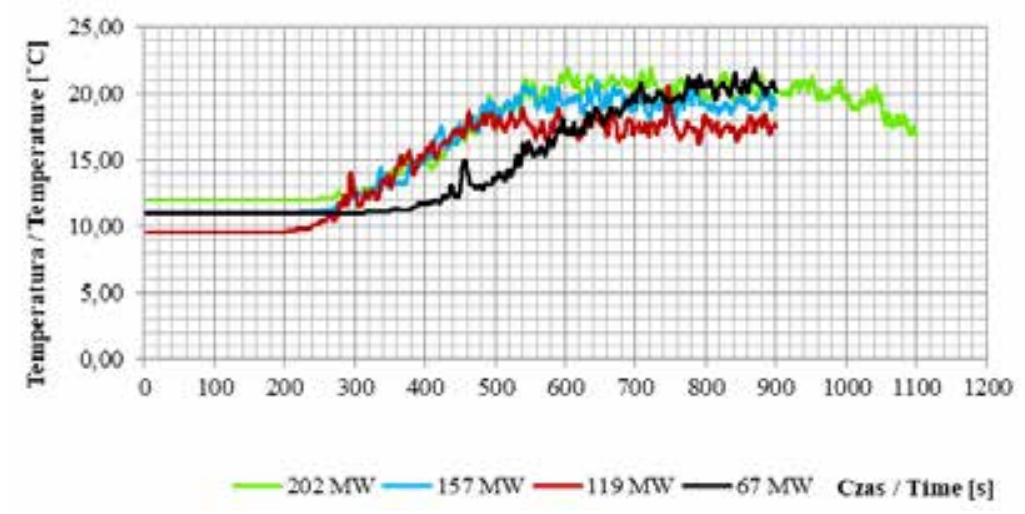

Rycina 12. Pomiar temperatury w odległości $15 \mathrm{~m}$ przed źródłem pożaru i na wysokości 1,8 m od poziomu podłogi Figure 12. Temperature at a distance of $15 \mathrm{~m}$ ahead of the fire source and a height of $1.8 \mathrm{~m}$ above the floor 


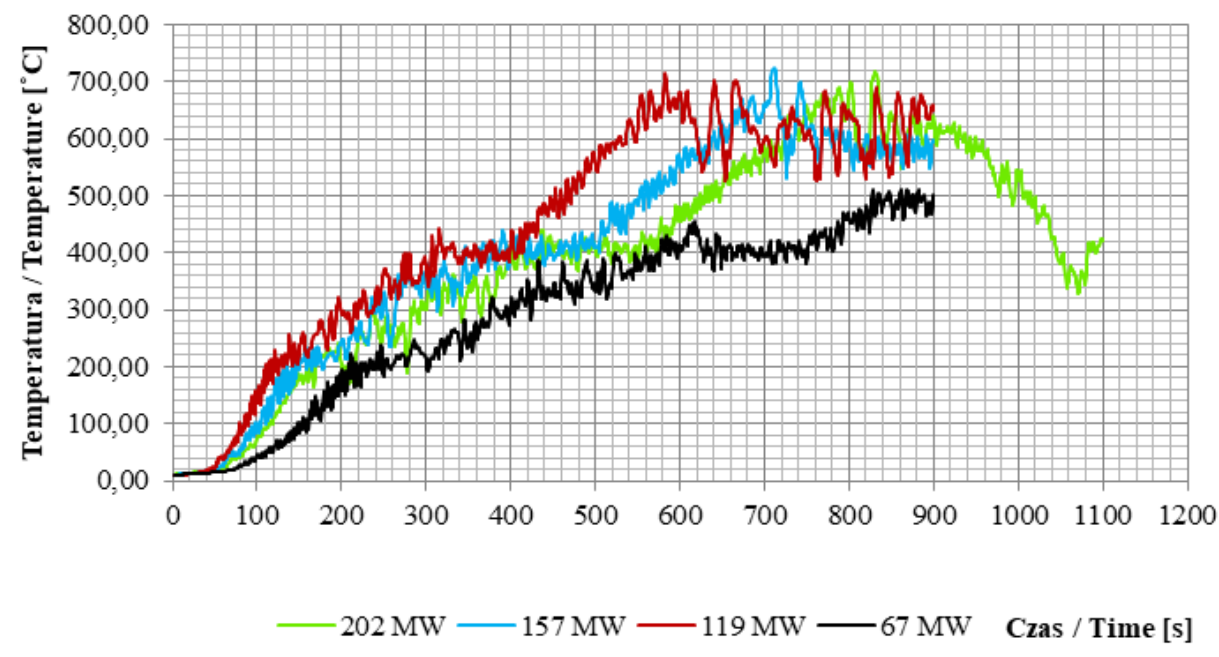

Rycina 13. Pomiar temperatury nad źródłem pożaru i na wysokości 1,8 $\mathrm{m}$ od poziomu podłogi

Figure 13. Temperature over the fire source and at a height of $1.8 \mathrm{~m}$ above the floor

Nad źródłem pożaru, we wszystkich rozpatrywanych przypadkach, temperatura zaczęła wzrastać już po około 40 sekundach - z wyjątkiem badania T4 (po około 80 sekundach). Krzywe temperatury dla niemal wszystkich mocy pożarów wzrastały z podobną szybkością do 400 sekundy. Jedynie krzywa pożaru o mocy $67 \mathrm{MW}$ wzrastała nieco wolniej. Po osiągnięciu tego czasu jej temperatura wynosiła $300^{\circ} \mathrm{C}$, a pozostałych testów $400^{\circ} \mathrm{C}$. Po przekroczeniu około 7 minuty, szybkość przyrostu temperatury dla poszczególnych pożarów nie była już jednakowa. Najwolniej pod względem mocy wzrastała temperatura najmniejszego pożaru (około $500^{\circ} \mathrm{C}$ nad źródłem). W pozostałych próbach temperatura maksymalna oscylowała w granicach $720^{\circ} \mathrm{C}$. Zaobserwować można nagły skok temperatury w krótkim odstępie czasowym. Dla krzywej, która reprezentowała moc pożaru równą $119 \mathrm{MW}$, przyrost ten wystąpił w przedziale około 400-600 sekundy. Z kolei przebieg temperatury dla 157 MW wzrastał gwałtownie od około 8 do 12 minuty. Pożar o mocy $202 \mathrm{MW}$ powodował najszybszy przyrost temperatury w czasie od około 10 do 13 minuty. Charakterystyczne jest, że nagły wzrost temperatury dla trzech największych mocy pożarów rozpoczynał się przy temperaturze około $400^{\circ} \mathrm{C}$.
In all the analysed cases, temperature started to increase above the fire source after approx. 40 seconds, except for T4 (in which case it started to grow after about 80 seconds). The temperature curves for nearly all heat release rates increased at a similar pace until 400 seconds. Only the curve for a heat release rate of $67 \mathrm{MW}$ rose a bit slower. After reaching this time, its temperature was $300^{\circ} \mathrm{C}$ while the temperature in the other tests was $400^{\circ} \mathrm{C}$. After about 7 minutes, the temperature increase rate for individual fires was no longer the same. Temperature of the smallest fire increased at the slowest rate, in terms of the heat release rate (about $500^{\circ} \mathrm{C}$ above the source). In the remaining tests, the maximum temperature revolved around $720^{\circ} \mathrm{C}$. One can observe a sudden spike in temperature within a short period of time. For the curve which represents a heat release rate of $119 \mathrm{MW}$, this increase took place in the 400-600 seconds range, whereas for $157 \mathrm{MW}$, temperature increased rapidly from about minute 8 to minute 12 . In the fire with a heat release rate of $202 \mathrm{MW}$, temperature increased at the fastest rate from about minute 10 to minute 13 . It is worth noting that for the three greatest heat release rates the sudden spike in temperature took place at a temperature of approx. $400^{\circ} \mathrm{C}$.

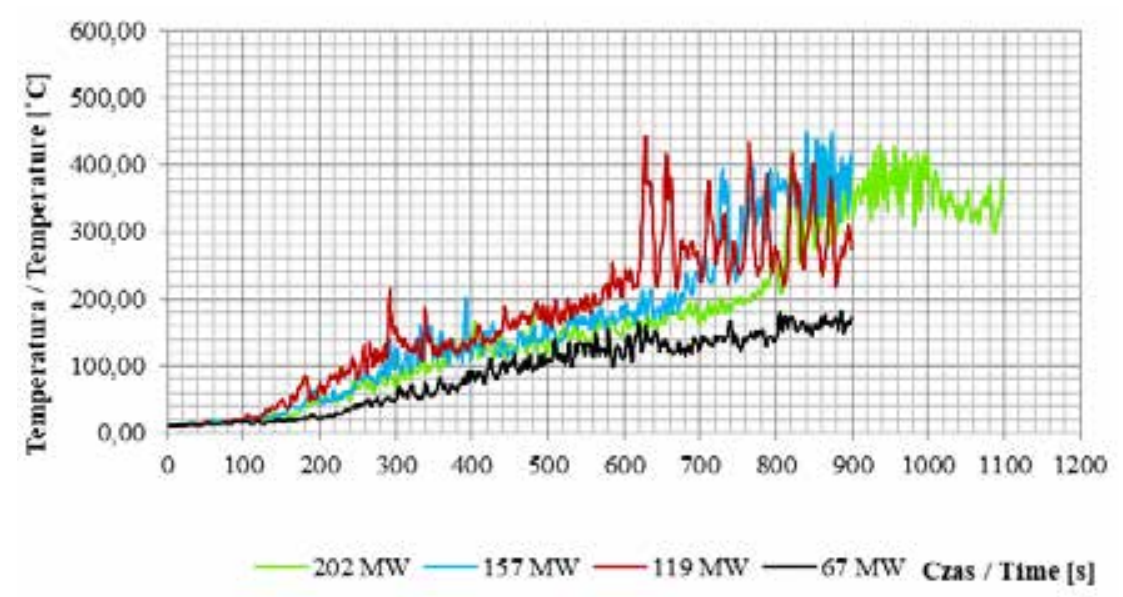

Rycina 14. Pomiar temperatury w odległości $10 \mathrm{~m}$ za źródłem pożaru i na wysokości 1,8 m od poziomu podłogi

Figure 14. Temperature at a distance of $10 \mathrm{~m}$ behind the fire source and at a height of $1.8 \mathrm{~m}$ above the floor 


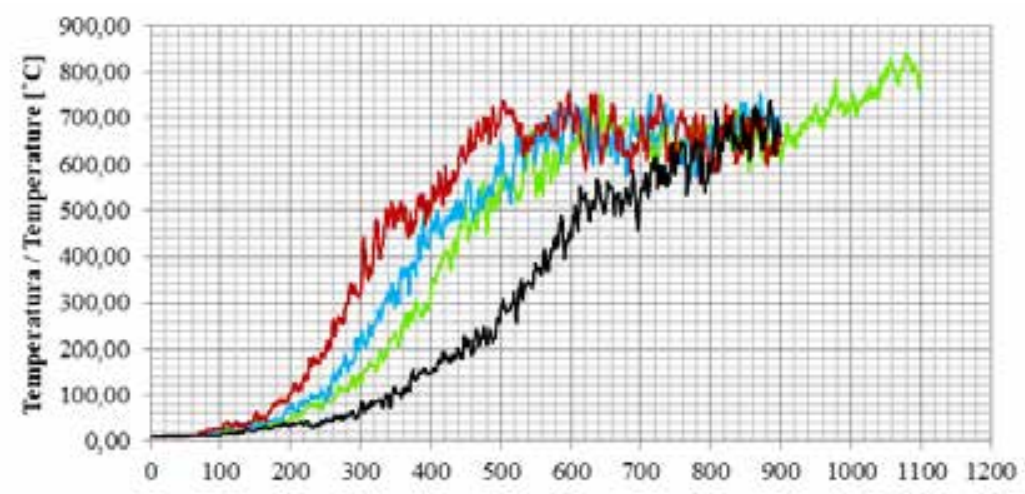

$-202 \mathrm{MW} \quad$ Cas / Time [s]

Rycina 15. Pomiar temperatury w odległości $20 \mathrm{~m}$ za źródłem pożaru i na wysokości 1,8 $\mathrm{m}$ od poziomu podłogi

Figure 15. Temperature at a distance of $20 \mathrm{~m}$ behind the fire source and at a height of $1.8 \mathrm{~m}$ above the floor

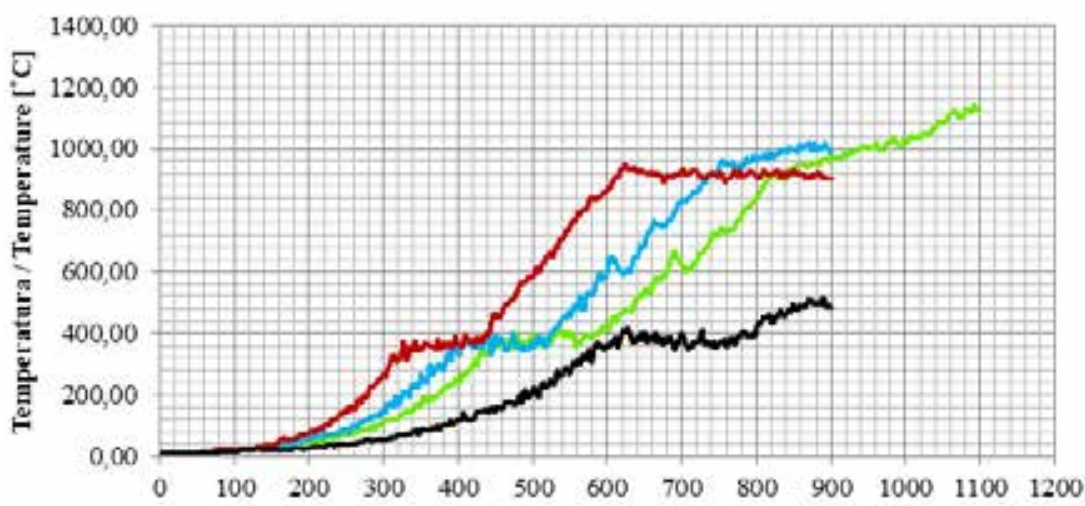

$-202 \mathrm{MW}-157 \mathrm{MW}-119 \mathrm{MW}-67 \mathrm{MW}$ Czas / Time [s]

Rycina 16. Pomiar temperatury w odległości $40 \mathrm{~m}$ za źródłem pożaru i na wysokości 1,8 $\mathrm{m}$ od poziomu podłogi

Figure 16. Temperature at a distance of $40 \mathrm{~m}$ behind the fire source and at a height of $1.8 \mathrm{~m}$ above the floor

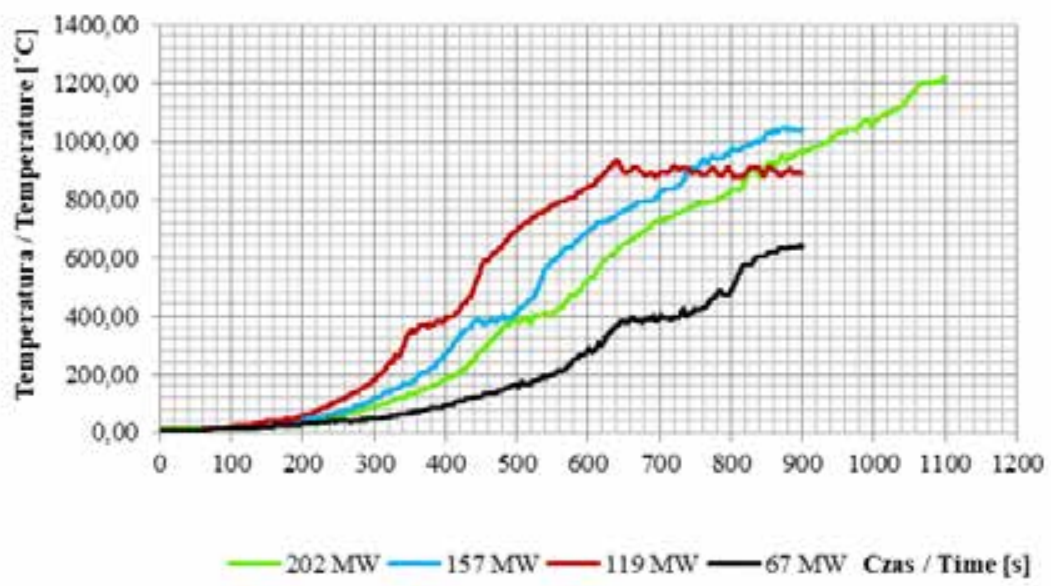

Rycina 17. Pomiar temperatury w odległości $70 \mathrm{~m}$ za źródłem pożaru i na wysokości 1,8 $\mathrm{m}$ od poziomu podłogi

Figure 17. Temperature at a distance of $70 \mathrm{~m}$ behind the fire source and at a height of $1.8 \mathrm{~m}$ above the floor

Przedstawione przebiegi temperatury obrazują jej wzrost w czasie, który uzależniony jest od odległości za źródłem pożaru. Z obserwacji wynika, że najwyższa temperatura na wysokości 1,8 $\mathrm{m}$ nad poziomem podłogi występowała w odległości 40 i 70 m od pożaru, natomiast najniższą temperaturę rzędu
The presented temperature curves illustrate temperature increase over time, which depends on the distance behind the fire source. The observations indicate that the highest temperature at a height of $1.8 \mathrm{~m}$ above the floor occurred at the distances of 40 and $70 \mathrm{~m}$ to the fire, while the lowest temperature $\left(500^{\circ} \mathrm{C}\right)$ for 
$500^{\circ} \mathrm{C}$, dla wszystkich prób z wyjątkiem pożaru o mocy $67 \mathrm{MW}$, odnotowano $10 \mathrm{~m}$ za źródłem. Prawdopodobną przyczyną powyższego był brak odpowiedniego mieszania się chłodnych prądów powietrza przepływających przez centrum pożaru dzięki wentylacji wzdłużnej. W masach powietrza wystąpiła różnica ciśnień, przez co nie doszło do wymiany ciepła pomiędzy warstwami. Po upływie około 800 sekund krzywa temperatury badania o największej mocy gwałtownie wzrosła. Stało się tak w przypadku pozostałych dwóch badań o średniej mocy. W najmniejszym pożarze wykres wzrastał stabilnie, bez większych odchyleń. Na rycinach 18 i 19 zauważyć można charakterystyczny przedział czasowy, w którym temperatura utrzymywała się na poziome $400^{\circ} \mathrm{C}$. Wnioskować można, że przepływ powietrza spowodowany działaniem wentylacji wpłynął na zatrzymanie wzrostu temperatury. W zależności od mocy pożaru zjawisko to rozpoczęło się w różnych momentach i trwało przez określony czas. W strefie podsufitowej temperatura znacząco wzrosła w porównaniu z wartościami otrzymanymi na wysokości 1,8 metra nad poziomem podłogi. W badanych odległościach od źródła pożaru temperatura rosła do określonych wartości maksymalnych, niezależnie od mocy pożaru. Różny jest natomiast czas osiągnięcia danej wartości temperatury. W badaniu, w którym przyjęto najmniejszą wartość, czas ten był najdłuższy. Działanie powietrza opóźniało znacznie akumulację ciepła w zależności od mocy pożaru. Zauważyć można, że wzrost ten następował nagle. Po osiągnięciu wartości maksymalnej temperatura nieznacznie spadała. Może to świadczyć o ustabilizowaniu się przepływu w górnych warstwach tunelu. Wraz ze zmniejszeniem odległości do źródła temperatura rosła. W odległości 70 metrów przed centrum pożaru temperatura wynosiła około $140^{\circ} \mathrm{C}$, natomiast termopara umieszczona w odległości 15 metrów wskazywała na około $350^{\circ} \mathrm{C}$. all tests, except for the fire with a heat release rate of $67 \mathrm{MW}$, was recorded $10 \mathrm{~m}$ behind the fire source. The above was probably caused by the cold air currents, which were flowing through the fire centre due to longitudinal ventilation, not mixing properly. There was a pressure difference between the air masses, which prevented heat transfer between the layers. After about $800 \mathrm{sec}-$ onds, the temperature curve for the highest heat release rate test increased rapidly. This was also the case for the two medium heat release rate tests. When it comes to the weakest fire, the curve increased steadily with no major deviations. Figures 18 and 19 present the characteristic period of time in which the temperate remained at $400^{\circ} \mathrm{C}$. One can conclude that the airflow caused by ventilation prevented the increase in temperature. Depending on the heat release rate, this phenomenon started at different moments and lasted for a specific time. In the ceiling zone, temperature increased significantly in comparison to the values recorded at 1,8 metres above the floor. At the tested distances from the source of fire, temperature increased to certain maximum values, regardless of the heat release rate. The time needed to reach a given temperature differed. In the test in which the lowest value was assumed, this time was the longest. The impact of air significantly delayed the accumulation of heat depending on the heat release rate. Of note is the fact that this increase was of a sudden character. After reaching the maximum value, temperature dropped slightly. This can prove that the flow stabilised in the upper sections of the tunnel. Also, the smaller the distance to the source, the higher the temperature. At a distance of 70 metres ahead of the fire centre, the temperature was about $140^{\circ} \mathrm{C}$, while the thermocouple located at a distance of 15 metres indicated approx. $350^{\circ} \mathrm{C}$.

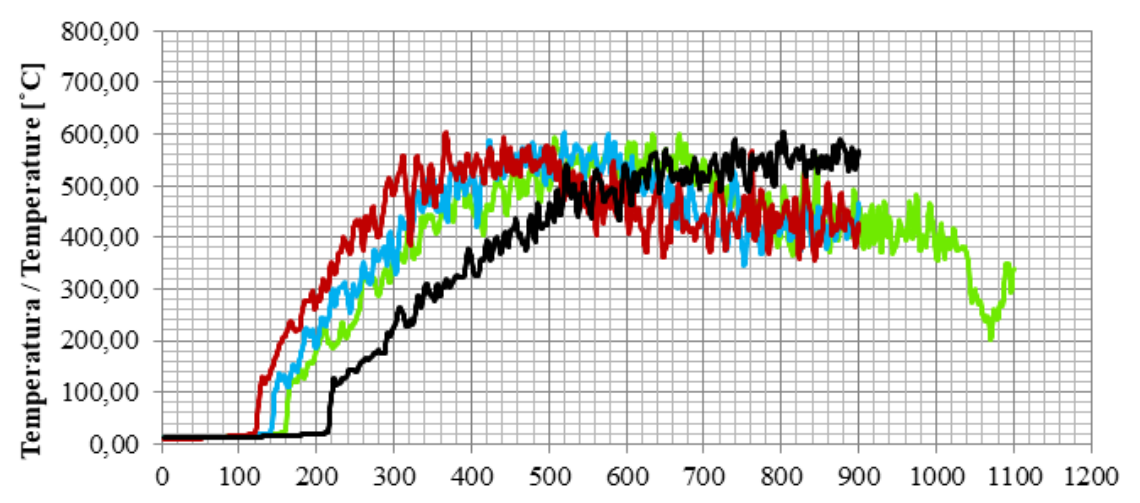

$-202 \mathrm{MW}-157 \mathrm{MW}-119 \mathrm{MW} \longrightarrow 67 \mathrm{MW}$ Czas / Time [s]

Rycina 18. Pomiar temperatury nad źródłem pożaru na wysokości $4,7 \mathrm{~m}$ od poziomu podłogi

Figure 18. Temperature over the fire source and at a height of $4.7 \mathrm{~m}$ from the floor

Na rycinie 18 zauważyć można charakterystyczne zjawisko. Dla pożarów o mocy 202 MW, 157 MW, 119 MW temperatura gwałtownie rosła $\mathrm{w}$ przedziale czasowym od 100 do 500 sekund do wartości maksymalnych. W tym okresie nastąpiło intensywne wydzielanie gorących gazów. Po około ośmiu minutach krzywe zaczęły opadać. Świadczy to o ustabilizowaniu się przepływu powietrza nad źródłem. Nadmiar ciepła
Figure 18 shows a characteristic phenomenon. For fires with heat release rates of $202 \mathrm{MW}, 157 \mathrm{MW}$ and $119 \mathrm{MW}$, temperature increased rapidly from second 100 to second 500 , to reach the maximum values. Hot gases were intensively generated within this period. After about eight minutes, the curves started to drop. This indicates that the airflow above the source became stabilised. Excess heat was transported by the ventilation sys- 
został przetransportowany za pomocą wentylacji ku wylotowi z tunelu. W krzywej opisującej badanie z użyciem mocy pożaru równej $67 \mathrm{MW}$ nie zanotowano takiego zjawiska. Wentylacja na bieżąco odprowadzała nadmiar gorących gazów pożarowych ku krańcowi tunelu. Na podstawie przeprowadzonych badań numerycznych zauważyć można, że większa część gorących gazów pożarowych transportowana była zgodnie z kierunkiem przepływu powietrza wymuszonego przez wentylację. Wraz z tymi gazami przenoszone było ciepło. Wartość temperatury maksymalnej została osiągnięta 10 metrów za źródłem pożaru oraz oscylowała w granicach $1400^{\circ} \mathrm{C}$. Maksymalna temperatura podczas pożaru w tunelu została obliczona na podstawie równań (22) i (23). tem to the outlet. No such phenome non was observed as regards the curve illustrating a $67 \mathrm{MW}$ fire. The ventilation system continuously discharged excess hot fire gases to the end of the tunnel. Based on the conducted numerical studies, one can observe that the major part of the hot fire gases was transported in the direction of the airflow forced by the ventilation system. Heat was transported along with these gases. The maximum temperature was reached 10 metres behind the fire source and fluctuated around $1400^{\circ} \mathrm{C}$. The maximum temperature during a tunnel fire was calculated using formulas (22) and (23).

Tabela 6. Dane przyjęte do obliczeń maksymalnej temperatury

Table 6. Data used for the calculation of the maximum temperature

\begin{tabular}{ccccccccc}
\hline $\begin{array}{c}\text { Numer testu } \\
\text { / Test number }\end{array}$ & $\begin{array}{c}Q \\
{[\mathbf{k W}]}\end{array}$ & $\begin{array}{c}g \\
{\left[\mathbf{m} / \mathbf{s}^{2}\right]}\end{array}$ & $\begin{array}{c}A \\
{\left[\mathbf{m}^{2}\right]}\end{array}$ & $\begin{array}{c}b_{f 0} \\
{[\mathbf{m}]}\end{array}$ & $\begin{array}{c}\rho_{0} \\
{\left[\mathbf{k g} / \mathbf{m}^{3}\right]}\end{array}$ & $\begin{array}{c}c_{p} \\
{[\mathbf{k J} / \mathbf{k g k}]}\end{array}$ & $\begin{array}{c}T_{0} \\
{[\mathbf{K}]}\end{array}$ & $\begin{array}{c}u_{0} \\
{[\mathbf{m} / \mathbf{s}]}\end{array}$ \\
\hline $\mathrm{T} 1$ & 202000 & $9,81 / 9.81$ & 1024 & $36,11729 / 36.11729$ & $1,2 / 1.2$ & $1,012 / 1.012$ & 285 & 2 \\
\hline $\mathrm{T} 2$ & 157000 & $9,81 / 9.81$ & 607 & $27,80734 / 27.80734$ & $1,2 / 1.2$ & $1,012 / 1.012$ & 284 & 2 \\
\hline $\mathrm{T} 3$ & 119000 & $9,81 / 9.81$ & 268 & $18,47705 / 18.47705$ & $1,2 / 1.2$ & $1,012 / 1.012$ & $282,5 / 282.5$ & 2 \\
\hline $\mathrm{T} 4$ & 67000 & $9,81 / 9.81$ & 195 & $15,76095 / 15.76095$ & $1,2 / 1.2$ & $1,012 / 1.012$ & 284 & 2 \\
\hline
\end{tabular}

Źródło: Opracowanie własne.

Source: Own elaboration.

Tabela 7. Wyniki obliczeń maksymalnej temperatury

Table 7. Calculation results of maximum temperature

\begin{tabular}{|c|c|c|c|}
\hline $\begin{array}{l}\text { Numer testu } \\
\text { / Test number }\end{array}$ & $\begin{array}{c}Q \\
{[\mathbf{k W}]}\end{array}$ & $\begin{array}{l}H_{e q} \\
{[\mathrm{~m}]}\end{array}$ & $\begin{array}{c}T \\
{\left[{ }^{\circ} \mathbf{C}\right]}\end{array}$ \\
\hline $\mathrm{T} 1$ & 202000 & 4 & 1350 \\
\hline $\mathrm{T} 2$ & 157000 & 4 & 1350 \\
\hline T3 & 119000 & 4 & 1350 \\
\hline T4 & 67000 & 4 & 1350 \\
\hline
\end{tabular}

Źródło: Opracowanie własne.

Source: Own elaboration.

Porównując wartości maksymalne uzyskane w symulacjach numerycznych w programie Fire Dynamics Simulator z wartościami obliczonymi na podstawie prostych modeli kalkulacyjnych, można stwierdzić, że poszczególne wartości temperatury maksymalnej w zależności od mocy pożaru odpowiadają sobie nawzajem. Świadczy to o tym, że model został wykonany poprawnie i zjawiska w nim zachodzące odwzorowują rzeczywistość.

Na rycinach 19-22 zaprezentowano pola rozkładu temperatury w zależności od mocy pożaru. Wentylacja, która wymuszała wzdłużny przepływ powietrza, oddziaływała na ogień, powodując przepływ gorących gazów pożarowych w stronę otworu wylotowego z tunelu. W zależności od symulacji, gradacja temperatury wzdłuż tunelu była różna. Na rycinach dobrze widoczne jest oddziaływanie przepływającego powietrza na temperaturę na wysokości 1,8 m od podłogi tunelu. Widać tam, że wysoka temperatura gromadziła się pod sufitem, natomiast świeże
After comparing the maximum values obtained in the numerical simulations performed in the Fire Dynamics Simulator with the values calculated with simple calculation models, one can state that the individual values of the maximum temperature correspond to one another, depending on the heat release rate. This proves that the model was designed correctly, and also that the phenomena observed within it reflect real conditions.

Figures 19-22 demonstrate temperature distribution for various heat release rates. The ventilation forcing the longitudinal airflow exerted an impact on the fire, resulting in the flow of hot fire gases towards the tunnel outlet. Depending on the simulation, the temperature gradient in the tunnel varied. The figures clearly show the impact of the airflow on the temperature at a height of $1.8 \mathrm{~m}$ above the floor of the tunnel. It can be noted that high temperature was accumulated under the ceiling, and low-temperature fresh air reached the fire centre. Hot 
powietrze o niskiej temperaturze docierało do centrum pożaru. Gorące gazy pożarowe nie rozprzestrzeniały się wraz z dymem w kierunku przeciwnym do kierunku działania wentylacji. fire gases did not spread with smoke in the direction opposite to ventilation.

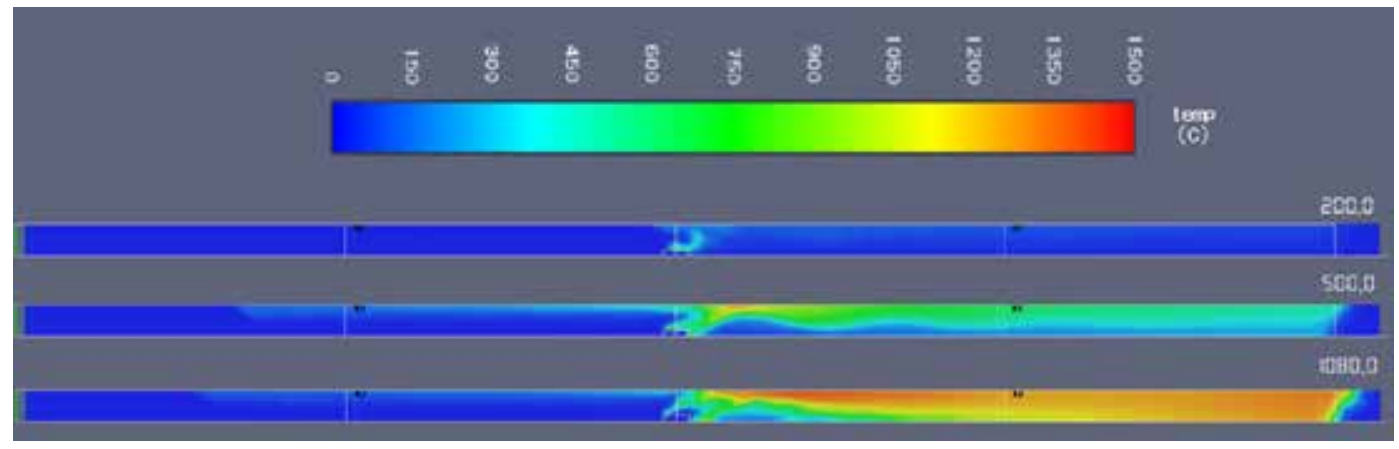

Rycina 19. Pole rozkładu temperatury, $Y=5, T 1$

Figure 19. Temperature distribution, $Y=5, T 1$

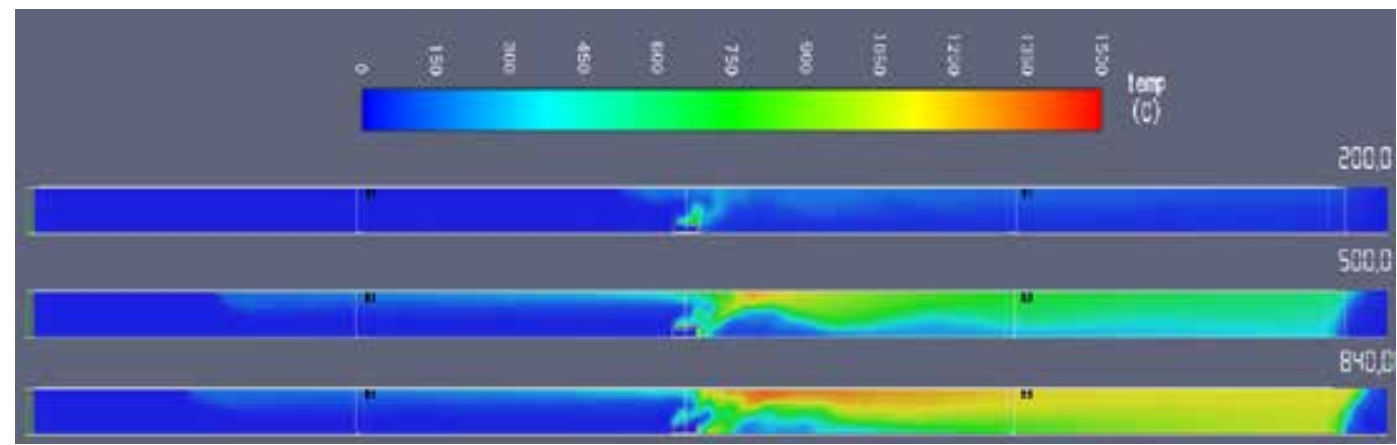

Rycina 20. Pole rozkładu temperatury, $Y=5, T 2$

Figure 20. Temperature distribution, $Y=5, T 2$

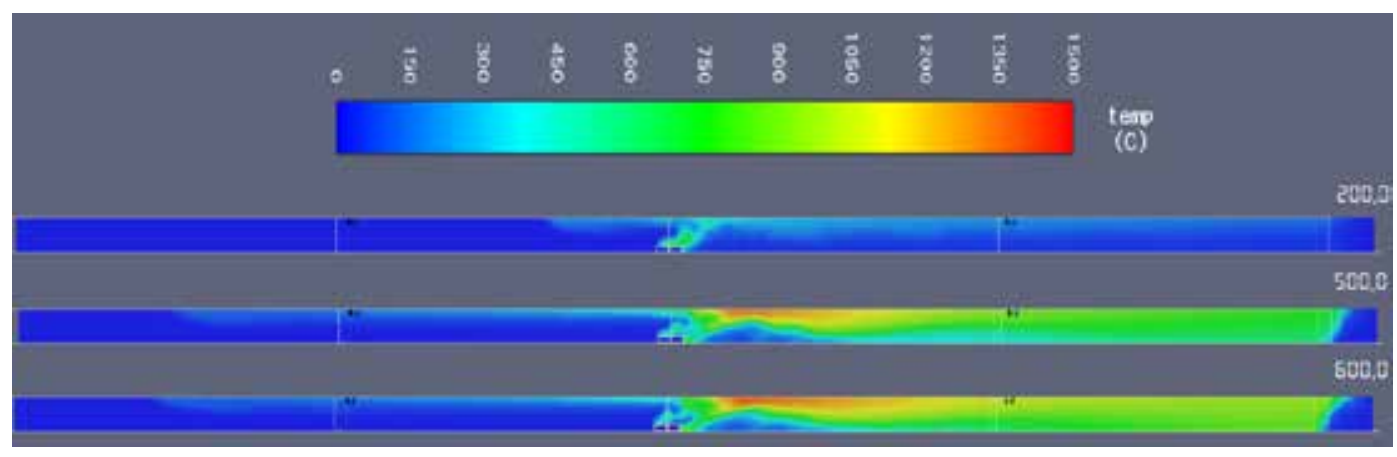

Rycina 21. Pole rozkładu temperatury, $Y=5, T 3$

Figure 21. Temperature distribution, $Y=5, T 3$

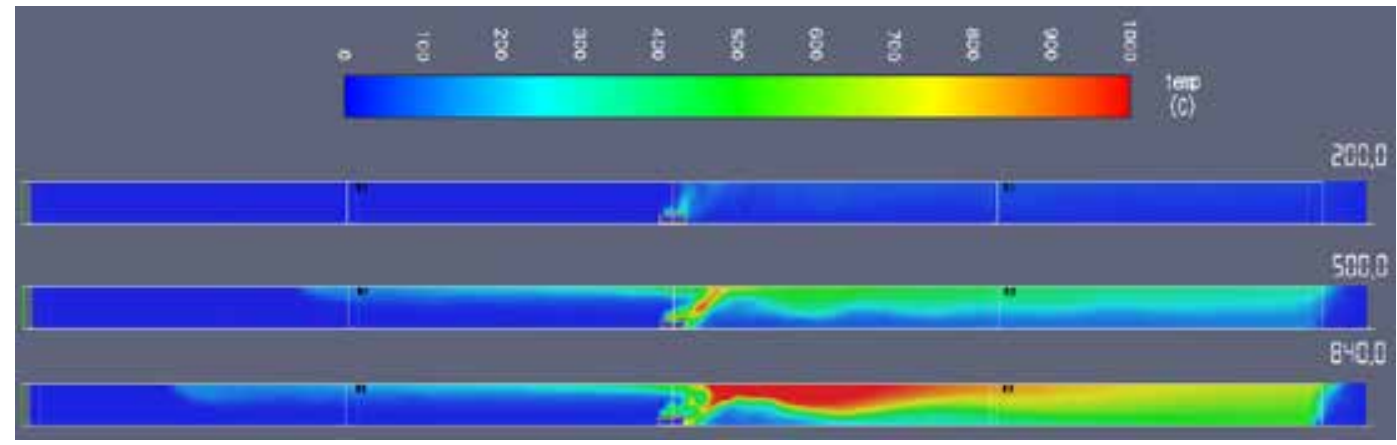

Rycina 22. Pole rozkładu temperatury, $Y=5, T 4$

Figure 22. Temperature distribution, $Y=5, T 4$ 


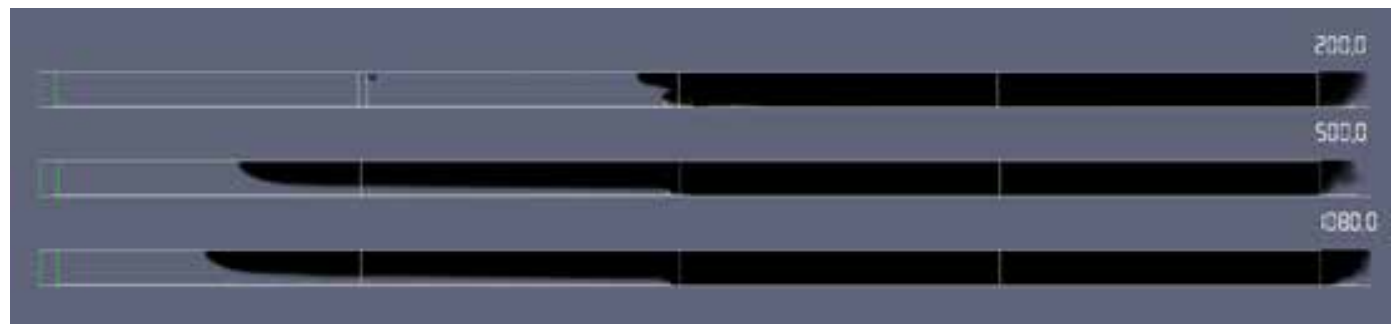

Rycina 23. Wizualizacja przepływającego dymu, $Y=5, T 1$

Figure 23. Smoke movement visualisation, $\mathrm{Y}=5, \mathrm{~T} 1$

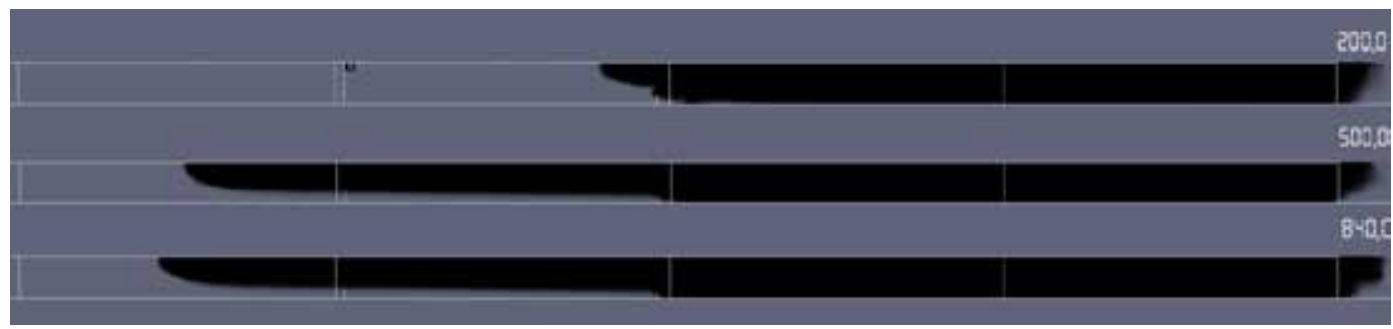

Rycina 24. Wizualizacja przepływającego dymu, $Y=5, T 2$

Figure 24. Smoke movement visualisation, $Y=5$, $T 2$

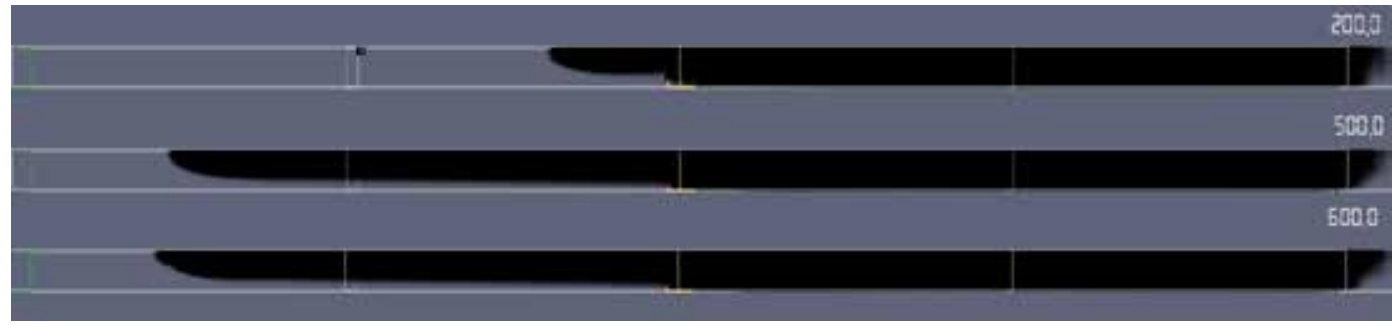

Rycina 25. Wizualizacja przepływającego dymu, $Y=5, T 3$

Figure 25. Smoke movement visualisation, $Y=5, T 3$

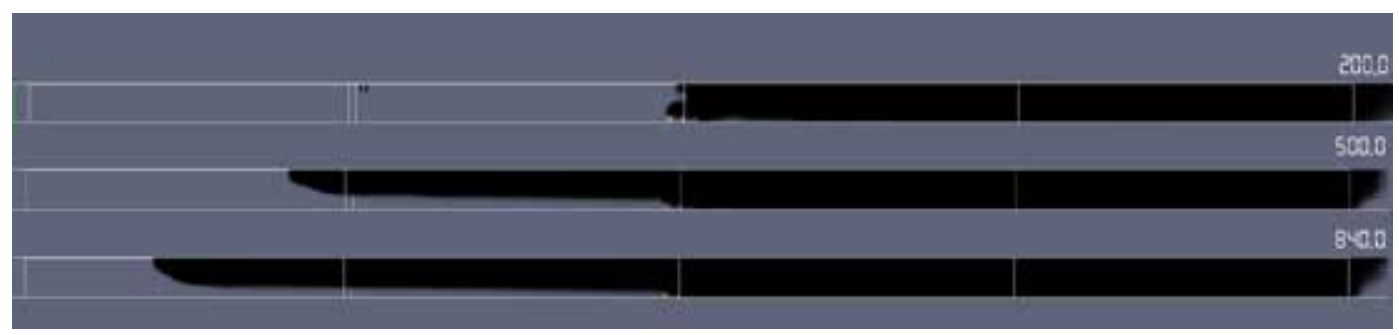

Rycina 26. Wizualizacja przepływającego dymu, $Y=5, T 4$

Figure 26. Smoke movement visualisation, $Y=5$, T4

Na podstawie rycin 23-26 zauważyć można, że przy każdej mocy pożaru występował efekt cofania się dymu, zwany w literaturze jako backlayering [3]. Jak przedstawiają wizualizacje, długość odcinka dymu dla wszystkich testów była podobna przy osiągnięciu maksymalnej mocy. Rycina 26 pokazuje, że w symulacji T4 w pierwszej fazie pożaru dym nie cofał się. Prędkość powietrza była wystarczająca, aby zatrzymać gazy pożarowe. Podobnie sytuacja wygląda w symulacji T1. W czasie do 200 sekund dym nieznacznie zaczął się cofać. Największą długość backlayeringu odnotowano w badaniu T3. Po około 8 minutach długości odcinków cofającego się dymu we wszystkich badaniach wyrównały się. Prędkość powietrza w tunelu nie spowodowała zatrzymania rozprzestrzeniania się dymu. Niezależnie od mocy pożaru raz z jego rozwojem dym przemieszczał się
Based on Figures 23-26, one can observe a phenomenon referred to as backlayering [3] with every heat release rate. As presented in the visualisations, the length of the smoke section for all the tests was similar once the maximum heat release rate was reached. Figure 26 shows that in T4, in the initial stage of the fire, no backlayering was observed. The airflow velocity was sufficient to stop the fire gases. A similar situation was observed in T1. Within 200 seconds smoke started to move back slightly. The longest backlayering was recorded in T3. After about $8 \mathrm{mi}-$ nutes, the length of the backlayering sections of smoke levelled off in all the tests. Air velocity in the tunnel did not stop the spread of smoke. Irrespective of the heat release rate, as the fire developed, the smoke moved opposite to the airflow direction up to the point where it stopped. In all cases, the smoke stop- 
niezgodnie z kierunkiem przepływu powietrza aż do miejsca, w którym się zatrzymał. We wszystkich przypadkach dym zatrzymał się w podobnej odległości od źródła pożaru. Na podstawie równań (1) i (2) obliczono długości odcinka cofającego się dymu. Wyniki zostały przedstawione w tabelach 8 i 9 . Według obliczeń długość odcinka powinna wynosić około 40 metrów i być jednakowa dla wszystkich mocy pożaru. Prędkość wzdłużna powietrza, którą należałoby wytworzyć, aby zapobiec cofaniu się dymu, wynosi około $3 \mathrm{~m} / \mathrm{s}$. ped at a similar distance to the fire source. Using equations (1) and (2), the length of the section of backlayering smoke was calculated. The results are presented in Tables 8 and 9. Based on the calculations performed, the length of this section should be approx. 40 metres, and it should not differ for any of the heat release rates. The longitudinal air velocity which should be generated to prevent backlayering is approx. $3 \mathrm{~m} / \mathrm{s}$.

Tabela 8. Dane wykorzystane do obliczeń długości odcinka cofającego się dymu oraz prędkości krytycznej Table 8. Data used for the calculation of the backlayering effect and critical velocity

\begin{tabular}{cccccccc}
\hline $\begin{array}{c}\text { Nr testu } \\
\text { / Test number }\end{array}$ & $\begin{array}{c}Q \\
{[\mathbf{k W ]}}\end{array}$ & $\begin{array}{c}\rho_{0} \\
{\left[\mathbf{k g} / \mathbf{m}^{3}\right]}\end{array}$ & $\begin{array}{c}c_{p} \\
{[\mathbf{k J} / \mathbf{k g k}]}\end{array}$ & $\begin{array}{c}g \\
{\left[\mathbf{m} / \mathbf{s}^{2}\right]}\end{array}$ & $\begin{array}{c}T_{0} \\
{[\mathbf{K}]}\end{array}$ & $\begin{array}{c}H \\
{[\mathbf{m}]}\end{array}$ \\
\hline $\mathrm{T} 1$ & 202000 & $1,2 / 1.2$ & $1,012 / 1.012$ & $9,81 / 9.81$ & 285 & 5 \\
\hline $\mathrm{T} 2$ & 157000 & $1,2 / 1.2$ & $1,012 / 1.012$ & $9,81 / 9.81$ & 284 & 5 \\
\hline $\mathrm{T} 3$ & 119000 & $1,2 / 1.2$ & $1,012 / 1.012$ & $9,81 / 9.81$ & $282,5 / 282.5$ & 5 \\
\hline $\mathrm{T} 4$ & 67000 & $1,2 / 1.2$ & $1,012 / 1.012$ & $9,81 / 9.81$ & 284 & 5 \\
\hline
\end{tabular}

Tabela 9. Długość cofającego się dymu oraz prędkość krytyczna

Table 9. Backlayering length and critical velocity

\begin{tabular}{ccc}
\hline $\begin{array}{c}\text { Nr testu } \\
\text { / Test number }\end{array}$ & $\begin{array}{c}L_{b} \\
{[\mathrm{~m}]}\end{array}$ & $\begin{array}{c}u_{c} \\
{[\mathrm{~m} / \mathrm{s}]}\end{array}$ \\
\hline $\mathrm{T} 1$ & $37,86051 / 37.86051$ & $3,011535 / 3.011535$ \\
\hline $\mathrm{T} 2$ & $37,86051 / 37.86051$ & $3,011535 / 3.011535$ \\
\hline T3 & $37,86051 / 37.86051$ & $3,011535 / 3.011535$ \\
\hline T4 & $37,86051 / 37.86051$ & $3,011535 / 3.011535$ \\
\hline
\end{tabular}

\section{Podsumowanie i wnioski}

Na podstawie wykonanych badań numerycznych przybliżono zjawiska, jakie zachodzą $w$ trakcie pożaru $w$ tunelu drogowym. Otrzymane dane można analizować i interpretować, wyciągając przy tym wnioski, które przyczynią się do zwiększenia bezpieczeństwa w tunelach. Jednym z najważniejszych aspektów, który ma bezpośredni wpływ na bezpieczeństwo ludzi podczas pożaru, jest dobór odpowiedniego systemu wentylacji. $\mathrm{Na}$ rynku istnieje wiele rozwiązań systemowych, posiadających zarówno wady, jak i zalety. W badanych przypadkach wykorzystano wentylację wzdłużną wraz z dwoma wentylatorami wywiewnymi. Wentylacja wzdłużna wytwarzała przepływ powietrza o prędkości $2 \mathrm{~m} / \mathrm{s}$ w całym przekroju tunelu. Zadaniem wentylatorów było usuwanie dymu i toksycznych produktów spalania. Na podstawie otrzymanych wyników można stwierdzić, że przepływ powietrza o prędkości $2 \mathrm{~m} / \mathrm{s}$ ogranicza rozprzestrzenianie się ciepła na wysokości 1,8 m od poziomu podłoża tunelu, niezależnie od mocy pożarów przyjętych w badaniach. Najwcześniej temperatura zaczęła wzrastać dla pożaru o mocy 119 MW, a najpóźniej dla pożaru o mocy $67 \mathrm{MW}$. W dalszych częściach tunelu temperatura zmieniała się $\mathrm{w}$ wąskim zakresie i nie przekroczyła $22^{\circ} \mathrm{C}$. Temperatura nad źródłem dochodziła do wartości $700^{\circ} \mathrm{C}$, natomiast za centrum pożaru maksymalna temperatura wyno-

\section{Summary and conclusions}

The phenomena that occur during a fire in road tunnels were described based on the numerical tests carried out. The obtained data can be analysed and interpreted, and conclusions can be drawn to improve safety in tunnels. The selection of the appropriate ventilation system is one of the most important aspects influencing the safety of people during a fire. There are many system solutions available on the market, which have their advantages and disadvantages. In the cases studied, longitudinal ventilation was used along with two exhaust fans. Longitudinal ventilation generated airflows at a velocity of $2 \mathrm{~m} / \mathrm{s}$ in the entire tunnel cross-section. The purpose of the fans was to remove smoke and toxic products resulting from the combustion process. Based on the obtained results, it can be concluded that an airflow rate of $2 \mathrm{~m} / \mathrm{s}$ reduces the spread of heat at a height of $1.8 \mathrm{~m}$ from the floor of the tunnel, regardless of the heat release rates adopted in the tests. The temperature started to increase firstly for a $119 \mathrm{MW}$ fire, and at the latest for a $67 \mathrm{MW}$ fire. In further sections of the tunnel, temperature changed to a very limited extent and did not exceed $22^{\circ} \mathrm{C}$. Above the source, temperature reached $700^{\circ} \mathrm{C}$, while behind the fire centre the maximum temperature was approx. $1200^{\circ} \mathrm{C}$. An analysis of temperature curves at a height of $1.8 \mathrm{~m}$ above the floor confirmed that, 
siła około $1200^{\circ} \mathrm{C}$. Analiza wykresów temperatur dla wysokości $1,8 \mathrm{~m}$ nad poziomem podłogi potwierdza, że mimo różnych mocy pożaru przyjętych w symulacjach, wentylacja powodowała zahamowanie rozprzestrzeniania się ciepła w kierunku przeciwnym do kierunku przepływu powietrza. Ciepło było transportowane ku otworowi wylotowemu z tunelu. Podobnie wyglądał rozkład temperatur dla strefy podsufitowej. W odległości $15 \mathrm{~m}$ od centrum pożaru temperatura wynosiła około $350^{\circ} \mathrm{C}$. Wraz ze wzrostem dystansu od źródła w stronę otworu wlotowego temperatura malała. W odległości $10 \mathrm{~m}$ za centrum pożaru temperatura osiągała swoją maksymalną wartość. W zależności od mocy pożaru czas osiągnięcia tej temperatury był różny. Wpływ wentylacji ograniczał kumulowanie się ciepła w jednym miejscu. Skuteczność wentylacji zależała od mocy pożaru, a także od czasu, który potrzebny jest do osiągnięcia jej maksymalnej wartości. Skuteczność ta była większa - to znaczy temperatura wzrastała po dłuższym czasie od rozpoczęcia spalania - dla pożarów T4 i T1. Najbardziej widoczne różnice w skuteczności działania wentylacji widać na rycinie 18 . W badaniu z najmniejszą mocą źródła pożaru czas potrzebny do uzyskania temperatury około $400^{\circ} \mathrm{C}$ był o 300 sekund dłuższy, niż w badaniu z wykorzystaniem mocy równej $119 \mathrm{MW}$. Od szybkości wydzielania ciepła zależy także ilość wydzielanego dymu. Wentylacja zastosowana w symulacjach nie zapobiegała tworzeniu się backlayeringu. Długość odcinka dymu przemieszczającego się w kierunku przeciwnym do kierunku przepływu powietrza $w$ każdym z badań sięgała około $70 \mathrm{~m}$ po czasie osiągnięcia maksymalnej mocy pożaru. Moment, w którym rozpoczynał się efekt backlayeringu zależał od ilości wydzielanego ciepła w jednostce czasu, a także od prędkości powietrza wytworzonej przez wentylację. Porównując symulacje, w której wykorzystano moc pożaru równą 119 MW i 67 MW, zauważyć można, że dym w symulacji T4 nie cofa się po 200 sekundach, a w symulacji T3 proces cofania już się rozpoczął. Wraz ze zmniejszeniem mocy pożaru wydzielanej w jednostce czasu skuteczność wentylacji rośnie. Z wykonanych badań wynika, że wentylacja najskuteczniej działała w badaniu T4, zaś jej najmniejszą skuteczność uzyskano w symulacji T3. Wraz z rozprzestrzenianiem się dymu zmniejszała się widoczność. Przepływ powietrza sprawił że warstwy dymu zaczęły się mieszać. Zaburzało to stratyfikację oraz obniżało widzialność za centrum pożaru. W związku z tym skuteczność wentylacji malała. Zauważyć można, że w 30 sekundzie badania widoczność zarówno przed, jak i za źródłem pożaru, na wysokości 1,8 m dla wszystkich symulacji umożliwiała bezpieczną ewakuację. Przepływ powietrza powodował kumulowanie się dymu przy ścianach tunelu. W pożarach, w których zastosowano moc źródła wynoszącą 157 MW i 119 MW po upływie 60 sekund, widoczność do około $50 \mathrm{~m}$ za centrum pożaru znacząco się pogorszyła. Duże ilości dymu wydzielane podczas tych pożarów mieszają się z wtłaczanym powietrzem, doprowadzając do zaburzenia stratyfikacji. Wraz ze wzrostem mocy pożaru przypadającej na jednostkę czasu zwiększała się ilość wydzielonego dymu. Powodowało to obniżenie skuteczności wentylacji. Na podstawie pomiarów prędkości powietrza wykonanych nad źródłem pożaru stwierdzono, że ruch powietrza na wysokościach 1,8 i 3,25 m odbywał się zgodnie z kierunkiem przepływu wytworzonym przez wentylację wzdłużną. W strefie despite the differences in the heat release rates assumed in the simulations, ventilation slowed down the spread of heat in the direction opposite to the airflow. The heat was transported towards the tunnel outlet. The temperature distribution for the ceiling zone was similar. At a distance of $15 \mathrm{~m}$ to the fire centre, temperature reached the level of around $350^{\circ} \mathrm{C}$. Moving towards the outlet, as the distance between the fire source increased, the temperature levels decreased. At a distance of 10 metres behind the fire centre, temperature reached its maximum value. The time of reaching this temperature varied depending on the heat release rate. The impact of ventilation limited the accumulation of heat in a single spot. The effectiveness of ventilation depended on the heat release rate, as well as on the time needed for it to reach the maximum value. This efficiency improved, i.e., the temperature increased after a longer period of time from the combustion, for T4 and T1 fires. The most striking differences in ventilation efficiency can be seen in Figure 18. In the test with the lowest heat release rate, the time needed to reach a temperature of approx. $400^{\circ} \mathrm{C}$ was by $300 \mathrm{sec}-$ onds longer than in the test of a fire with a heat release rate of $119 \mathrm{MW}$. The heat release rates also determine the amount of smoke generated. The ventilation applied in the simulations did not prevent backlayering. The length of the section of smoke moving in the opposite direction to the airflow in each of the tests equalled about $70 \mathrm{~m}$ after the maximum heat release rate had been reached. The moment of the onset of backlayering depended on the amount of heat generated in a unit of time, as well as on the velocity of the airflow generated by ventilation. By comparing the simulations with heat release rates of $119 \mathrm{MW}$ and $67 \mathrm{MW}$, it can be noted that smoke in T4 does not backlayer after 200 seconds, and that it has already started in T3. The efficiency of ventilation improves as the heat release rate per a unit of time decreases. The results of the study demonstrate that ventilation was the most effective in T4, and the least effective in T3. Visibility decreased along with the spread of smoke. Airflow resulted in the mixing of smoke layers. This disturbed stratification and reduced visibility behind the fire centre. Thus, the efficiency of ventilation decreased. One can note at second 30 of the test that the visibility both ahead of and behind the fire source, at a height of $1.8 \mathrm{~m}$, allowed safe evacuation in all simulated scenarios. The airflow resulted in the accumulation of smoke near the walls of the tunnel. In the fires with heat release rates of $157 \mathrm{MW}$ and $119 \mathrm{MW}$, visibility behind the fire centre deteriorated significantly after 60 seconds. Large volumes of smoke generated during these fires mix up with the force-fed air, causing disturbed stratification. As the heat release rate per unit of time increased, the amount of the generated smoke grew. This caused a decrease in ventilation efficiency. Based on air velocity measurements taken above the fire source, it was found that at heights of $1.8 \mathrm{~m}$ and $3.25 \mathrm{~m}$ air moved in the direction of the flow generated by longitudinal ventilation. In the ceiling zone, the airflow velocity was insufficient to prevent the spread of smoke and temperature towards the tunnel inlet. The heat release rate had a minimum impact on these velocities, but it influenced the time required to reach them. Due to the phenomena taking place under the ceiling, the airflow velocities were unstable. The efficiency of fire ventilation in road 
podsufitowej prędkość przepływu powietrza nie była wystarczająca, aby zapobiec rozprzestrzenianiu się dymu i temperatury w stronę otworu wlotowego do tunelu. Moc pożaru miała minimalny wpływ na te prędkości, jednakże oddziaływała na czas ich osiągnięcia. W wyniku zjawisk zachodzących pod sufitem prędkości przepływu powietrza były niestabilne. Skuteczność wentylacji pożarowej zastosowanej w tunelu drogowym zależy od wielu czynników. Badania przeprowadzone w pracy pozwalają na stwierdzenie, że skuteczność wentylacji zależy między innymi od mocy pożaru wydzielanej w jednostce czasu. Wraz ze wzrostem tego parametru maleje skuteczność systemów odprowadzania dymu i gorących gazów pożarowych. Podczas badań nie zauważono wpływu wentylatorów wyciągowych na skuteczność działania wentylacji pożarowej. Aby określić ten wpływ, należy przeprowadzić dodatkowe badania. Dodatkowo należałoby kontynuować przedmiotowe badanie z użyciem mniejszych siatek obliczeniowych, $\mathrm{np} .10 \times 10 \mathrm{~cm}$, jak również przy zastosowaniu innych modeli turbulencji. Pozwoliłoby to na dokonanie szerszej oceny wpływu ruchów powietrza wokół wentylatorów na przepływ w całym przekroju tunelu.

\section{Literatura / Literature}

[1] Mizieliński B., Kubicki G., Wentylacja pożarowa. Oddymianie, WNT, Warszawa 2012

[2] Pofit-Szczepańska M., Półka M., Zabójcze produkty spalania, "Przegląd Pożarniczy" 2014, 7.

[3] Inganson H., Li Y.Z, Lönnermark A., Tunnel fire dynamics, Springer, 2015.

[4] McGrattan K., McDermott R., Weinschenk C., Overholt K., Hostikka S., Floyd J., Fire Dynamics Simulator User's Guide, National Institute of Standards and Technology Special Publication 1019, 2013.

BRYG. DR HAB. INŻ. RAFAt POROWSKI - w roku 2002 ukończył studia na Wydziale Inżynierii Bezpieczeństwa Pożarowego w Szkole Głównej Służby Pożarniczej. W 2013 r. uzyskał stopień doktora nauk technicznych na Wydziale Mechanicznym Energetyki i Lotnictwa Politechniki Warszawskiej, a w 2019 r. stopień doktora habilitowanego nauk technicznych na Wydziale Instalacji Budowlanych, Hydrotechniki i Inżynierii Środowiska Politechniki Warszawskiej. Jest adiunktem na Wydziale Inżynierii Środowiska, Geomatyki i Energetyki Politechniki Świętokrzyskiej w Kielcach. Specjalność - procesy spalania i modelowanie numeryczne. Od 2018 r. petni funkcję zastępcy dyrektora Centrum Naukowo-Badawczego Ochrony Przeciwpożarowej - PIB.

MŁ. KPT. INŻ. PAWEŁ BAŃKOWSKI - absolwent dziennych studiów inżynierskich na Wydziale Inżynierii Bezpieczeństwa Pożarowego w Szkole Głównej Służby Pożarniczej, oficer Państwowej Straży Pożarnej.

Mt. BRYG. MGR INŻ. WOJCIECH KLAPSA - absolwent Szkoły Głównej Służby Pożarniczej w Warszawie (2004) i Wojskowej Akademii Technicznej w Warszawie (2006) Wydziału Chemii. Służbę rozpoczął tunnels is conditional on a number of factors. The tests carried out within this work allow us to conclude that the efficiency of fire ventilation depends, among other things, on the heat release rate in a unit of time. As this parameter grows, the efficiency of smoke and hot fire gas extraction systems decreases. During the tests, the exhaust fans were found to have no impact on the effectiveness of fire ventilation. In order to determine it, further tests should be conducted. In addition, the study at hand should be continued using smaller grids, e.g. $10 \times 10 \mathrm{~cm}$, also with other turbulence models applied. This would make it possible to evaluate, in broader terms, the impact of air movement around the ventilators on the airflow in the entire tunnel cross-section.

[5] http://pyrosim.pl/ [dostęp: 28.11.2018].

[6] Nawrat S., Napieraj S., Schmidt-Polańczyk N., Zastosowanie modelowania numerycznego dla oceny bezpieczeństwa użytkowników tunelu drogowego z wentylacją wzdłużną w warunkach pożaru, Budownictwo podziemnej bezpieczeństwo w komunikacji drogowej i infrastrukturze miejskiej, AGH, Kraków 2016.

[7] Inganson H., Li Y.Z., Lönnermark A., Runehamar tunel fire tests, “Fire Safety Journal" 2015, 71, 134-149.

BRIG. RAFAŁ POROWSKI, D.SC. ENG. - in 2002 he graduated from the Faculty of Fire Safety Engineering of the Main School of Fire Service. In 2013 he obtained the degree of Doctor of Technical Sciences at the Faculty of Power and Aeronautical Engineering of the Warsaw University of Technology, and in 2019 he was conferred a post-doctoral degree in technical sciences at the Faculty of Building Services, Hydro and Environmental Engineering of the Warsaw University of Technology. Currently works as an Assistant Professor at the Faculty of Environmental, Geomatic and Energy Engineering of the Kielce University of Technology. He specialises in combustion processes and numerical modelling. Since 2018, he has been Deputy Director of the Scientific and Research Centre for Fire Protection - National Research Institute.

JUNIOR CPT. PAWEŁ BAŃKOWSKI, ENG. - a graduate of the Faculty of Fire Safety Engineering at the Main School of Fire Service. He is an officer of the State Fire Service.

JUNIOR BRIG. WOJCIECH KLAPSA, M.SC. ENG. - graduated from the Main School of Fire Service in Warsaw (2004) and the Military University of Technology in Warsaw (2006) in chemistry. He began 
w Jednostce Ratowniczo-Gaśniczej KM w Warszawie, a następnie podjął służbę w Komendzie Wojewódzkiej PSP w Warszawie w wydziale kontrolno-rozpoznawczym. Obecnie pełni służbę w Centrum Naukowo-Badawczym Ochrony Przeciwpożarowej Państwowym Instytucie Badawczym w Józefowie w Zespole Laboratoriów Procesów Spalania i Wybuchowości na stanowisku zastępcy kierownika. Autor lub współautor artykułów o tematyce bezpieczeństwa pożarowego oraz właściwości palnych materiałów budowlanych. W CNBOP-PIB zajmuje się tematyką ekspertyz technicznych budynków, opinii sądowych w zakresie ustalania przyczyn pożarów oraz badaniami w zakresie reakcji na ogień wyrobów budowlanych, a także wyznaczaniem parametrów wybuchowych substancji palnych. Prelegent na konferencjach krajowych i zagranicznych, a także wykładowca podczas ćwiczeń oraz warsztatów i treningów na szkoleniach i kursach.

MGR INŻ. MARIOLA STARZOMSKA - asystent na Wydziale Inżynierii Środowiska, Geomatyki i Energetyki Politechniki Świętokrzyskiej, gdzie w Katedrze Fizyki Budowli i Energii Odnawialnej zajmuje się badaniami naukowymi w obszarze fizyki budowli oraz budownictwa.

MGR INŻ. ARTUR WIĘCKOWSKI - pracownik Wydziału Inżynierii Środowiska, Geomatyki i Energetyki Politechniki Świętokrzyskiej, gdzie w Katedrze Fizyki Budowli i Energii Odnawialnej zajmuje się badaniami naukowymi w obszarze fizyki budowli oraz budownictwa. his service in the Firefighting and Rescue Unit of the municipal fire brigade in Warsaw and then took up work in the Inspection and Identification Department of the Regional Headquarters of the State Fire Service in Warsaw. He is currently employed as the Deputy Head of the Combustion Processes and Explosion Laboratory of CNBOP-BIP in Józefów. Author or co-author of articles on the subject of fire safety and properties of flammable construction materials. His work at CNBOP-BIP focuses on technological evaluations of buildings, court opinions on the causes of fires and tests of reaction-to-fire performance of construction products, as well as the determination of explosive parameters of flammable substances. He has spoken at national and international conferences and worked as a lecturer teaching classes and conducting training sessions as part of various courses.

MARIOLA STARZOMSKA, M.SC. ENG. - an assistant at the Faculty of Environmental, Geomatic and Energy Engineering, Kielce University of Technology, where in the Department of Building Physics and Renewable Energy she carries our research in building physics and construction.

ARTUR WIĘCKOWSKI, M.SC. ENG - an employee at the Faculty of Environmental, Geomatic and Energy Engineering, Kielce University of Technology, where in the Department of Building Physics and Renewable Energy she carries our research in building physics and construction. 